Article

\title{
Sustainability of Smallholder Livelihoods in the Ecuadorian Highlands: A Comparison of Agroforestry and Conventional Agriculture Systems in the Indigenous Territory of Kayambi People
}

\author{
Raúl Córdova ${ }^{1, *}$, Nicholas J. Hogarth ${ }^{1,2}$ (i) and Markku Kanninen 1 (i) \\ 1 Viikki Tropical Resources Institute (VITRI), Department of Forest Sciences; University of Helsinki, \\ Latokartanonkaari 7, P.O. Box 27, 00014 Helsinki, Finland; nicholas.hogarth@helsinki.fi (N.J.H.); \\ markku.kanninen@helsinki.fi (M.K.) \\ 2 Helsinki Institute of Sustainability Science (HELSUS), University of Helsinki, 00014 Helsinki, Finland \\ * Correspondence: raul.cordova@helsinki.fi; Tel.: +593-2237-5372 or +593-997-756-895
}

Received: 9 March 2018; Accepted: 5 April 2018; Published: 10 April 2018

check for updates

\begin{abstract}
Smallholder farming constitutes an important but marginalized sector, responsible for most of the world's agricultural production. This has a significant influence in the land use/cover change process and agrobiodiversity conservation, especially in mountainous regions of the developing world. Thus, the maintenance of sustainable smallholder farming systems represents a key condition for sustainable land management and to safeguard the livelihoods of millions of rural households. This study uses a combination of biophysical and socioeconomic data based on household interviews to compare 30 highland agroforestry systems and 30 conventional agriculture systems, to determine which system provides better conditions to support sustainable livelihoods for smallholder farmers. The interview data is based mainly on the perceptions of Kayambi indigenous farmers who use these farming systems to support their livelihoods. Independent-Samples $t$ Test and descriptive statistics were applied to analyse the data from 60 farms. The results indicate that agroforestry systems contain greater agrobiodiversity; more diversified livelihoods; better land tenure security and household income; more diversified irrigation sources and less dependency on rainfall than conventional systems. These findings highlight the role of agroforestry systems in supporting sustainable livelihoods of smallholder farmers in mountainous areas.
\end{abstract}

Keywords: agroforestry and conventional farming systems; smallholder farmers' perceptions; sustainable mountain livelihoods; agrobiodiversity; indigenous people; tropical highlands

\section{Introduction}

An estimated 570 million farms throughout the world are considered to be small or family operated [1]. Smallholder farms are characterized by being less than 10 ha in size [2]; and being family-operated, with limited or no hired labour. In many cases, the smallholders live with poverty, food insecurity, and with limited access to markets and services [3,4]. Despite their socioeconomic and environmental limitations, smallholder farmers play an important role in food supply chains and economies at the local, regional and global level, especially in the developing world, e.g., [1-6]. Lowder et al. [1] explain the importance of smallholder farmers, reporting that about $75 \%$ of global agricultural land is occupied by smallholders or family farms, which are also responsible for the majority of the world's agricultural production. Consequently, smallholder farmers have an important influence in the process of land-use/land-cover change and agrobiodiversity conservation [5]. 
In the Latin American and Caribbean (LAC) context, recent evidence indicates that the situation and importance of smallholder farmers supporting food production systems, livelihoods of rural and urban households, and local and regional economies, have some important similarities and significant differences compared to the regional and global context $[1,4,6,7]$. One major difference between LAC and other regions is the greater agricultural land grabbing resulting in the consolidation of large landholdings in the hands of landlords and agribusiness companies [1,7]. The higher land consolidation and increasing land grabbing in LAC [8,9] is reducing the possibilities for smallholder access to agricultural land, and usually accelerates the expansion of agricultural frontiers, fragmentation and overexploitation of existing agricultural land and water resources [10]. The marginalization and poverty of smallholder farmers' households, also increases inequality and reduced access to farmland and other assets for production, such as access to technology, information, credit and technical support $[10,11]$. In line with the global context, smallholder farmers in LAC play a key role in supporting food production systems and local and regional economies [12]. Altieri et al. [13] reported that smallholder farmers in LAC represents a population of about 66 million people, including 40-55 million indigenous people who are responsible for the production of the main staple foods consumed in the region; including maize, beans, and potatoes. A study conducted in six LAC countries by Soto et al. [6] found that smallholder farming employed between $57 \%$ of the agricultural sector and $77 \%$ of the rural employment.

In the case of Ecuador, the situation of smallholder farmers appears similar to the general trends in the LAC region. The increasing trend of land consolidation, land grabbing, and unequal distribution of agricultural lands and other assets for production are threatening the maintenance and improvement of smallholders' livelihoods [14-16]. Agricultural land consolidation is also a significant environmental and socioeconomic problem in Ecuador. Approximately $76 \%$ of farmers are smallholders (with farms $<10 \mathrm{ha}$ ), but they occupy only $12 \%$ of the agricultural land. In contrast, $6 \%$ of farmers have large holdings (>50 ha) and occupy $61 \%$ of the land $[15,17,18]$. Land consolidation and grabbing are associated with the concentration of other productive assets, especially water, which is also concentrated in few and large landholdings $[14,15,19,20]$. The accumulation of land and water as primary productive assets is closely related to the increase of marginalization, poverty and malnutrition, which are common problems experienced by Ecuadorian smallholders [15,21]. The unequal access to land and water is strongly connected with socioeconomic and cultural discrimination, whereby agricultural land areas with high levels of fragmentation commonly coincide with areas having high poverty levels, and where most indigenous people live. These areas are located mainly in the highlands, which are characterized by steep slopes and harsh environmental conditions [14-16].

Smallholder farmers in Ecuador play an important role in local food supply for millions of rural and urban households and livelihoods. Data from the last agricultural national census 2000 [18] (Figure A1) and other publications [6,12,19,21-23], indicate that most of the staple food consumed in the country is produced by smallholder farmers, giving them a strategic role supporting agrobiodiversity, food security and food sovereignty. Although there is a lack of information detailing the contribution of smallholder farmers to the economy, official data shows that the agriculture sector, which includes smallholdings, contributes $9 \%$ to total GDP [15,24], 15.4\% of the non-petroleum GDP, and directly employs about $70 \%$ of rural workers [15]. Furthermore, the smallholder farming sector employs about $16 \%$ of permanent and $40 \%$ of non-permanent hired labour in the country [18]. Considering that smallholder farming mainly uses family labour, these figures represent an important contribution by the smallholder sector to rural employment and livelihoods in Ecuador.

In this context, and taking into account that smallholder farming in the developing world is also a very culturally and ecologically heterogeneous sector [25], the aim of this paper is to provide a socioeconomic and environmental analysis of how different types of production systems contribute to the sustainability of smallholder livelihoods in the tropical highlands. The analysis compares smallholder farmers' perceptions of the main biophysical and socioeconomic components of the farming systems that support their livelihoods. A comparison is made within and between two types 
of smallholder production systems; agroforestry systems (AFS) and conventional agricultural systems (CAS). CAS are commonly found in the Indigenous Territory of Kayambi People (ITKP), while AFS are less practiced but there is an increasing interest of smallfarmer groups and local institutions, on the implementation of this type of farming systems. The main element differentiating AFS from CAS in this study is the proportion of the farm area covered by trees or shrubs (described in detail in Section 2.2), which influences the biophysic and socioeconomic functioning of the farming system [26].

The main research question addressed in this study is: How sustainable are smallholder AFS and CAS in the ITKP, Ecuador? This question will be addressed through two sub-questions, which are: (1) What are the main biophysical and socioeconomic characteristics and differences between current AFS and CAS? and (2) Which system provides better opportunities to enhance sustainable smallholder farmers' household incomes and livelihoods?

This paper presents a simplified multidisciplinary case study and contributes towards an improved understanding of the structure and dynamics that maintain and enhance sustainable livelihoods of smallholder farmers in highlands.

\section{Materials and Methods}

\subsection{Study Area}

The research area was located in the Northern Highland Andes of Ecuador as part of the ITKP (Figure 1). The biophysical and socioeconomic conditions, and problems affecting smallholders in the study area are similar, and in most cases are worse than the conditions and problems of other highland smallholders throughout the country (Figure 2). The Kayambi's territory includes approximately $1329 \mathrm{~km}^{2}$ [27], distributed mainly along the rural highlands of three provinces, six cantons, 16 parishes and 168 communities [28-30]. The territory covers an altitude range of 2000 (low valleys) to $5790 \mathrm{~m}$ (Cayambe Volcano), along the eastern and western volcanic mountain chains and between the inter-Andean valleys. The Inter-Andean valleys are the lower areas between the two mountain chains and are characterized by the flat or low-sloping topography, while the hillsides are highly eroded with high slopes and little flat land [31]. These geomorphological and topographic features contribute to the formation of a variety of bioclimatic and biotic zones [32,33].

The ITKP includes areas under agricultural production interspersed with natural and semi-natural native ecosystem remnants, especially highland grasslands known locally as "Páramo". The soils in the ITKP are classified as andisols, mollisols and inceptissols, based on volcanic ash and distinguished by their productivity and fertility [34]. The rainy season usually occurs from September to April with a mean annual rainfall ranging from 250 to $2000 \mathrm{~mm}[32,35]$. The rainy season is commonly distributed in two rain periods, with the first occurring from October to November and the second from February to April. An intermediate period-summer-occurs from June to August and is characterized by dryness, strong winds and high solar radiation and temperature [32]. The temperature varies from dry and temperate in low inter-Andean valleys with average annual temperatures of 12 to $18^{\circ} \mathrm{C}$, to the cold and humid highland grasslands with average annual temperatures of 3 to $6{ }^{\circ} \mathrm{C}$ [36].

The ITKP has a population of 154,437, and according to the last national population census [37], the mean concentration of self-recognized indigenous population in the territory is approximately $40 \%$ (Table A1 in the Appendix A). The indigenous population is unevenly distributed, exceeding $70 \%$ in some areas, and more than $90 \%$ in others (Table A1, Appendix A). The Kayambi's territory is not an official administrative territory, but rather it can be considered as ancestral territory, managed by the Kayambi people according to their customs and recognized by local, national, international, public and private institutions. These figures reveal the indigenous cultural dominance in the territory, which has a significant influence over the management practices implemented in the traditional farming systems throughout the territory. 


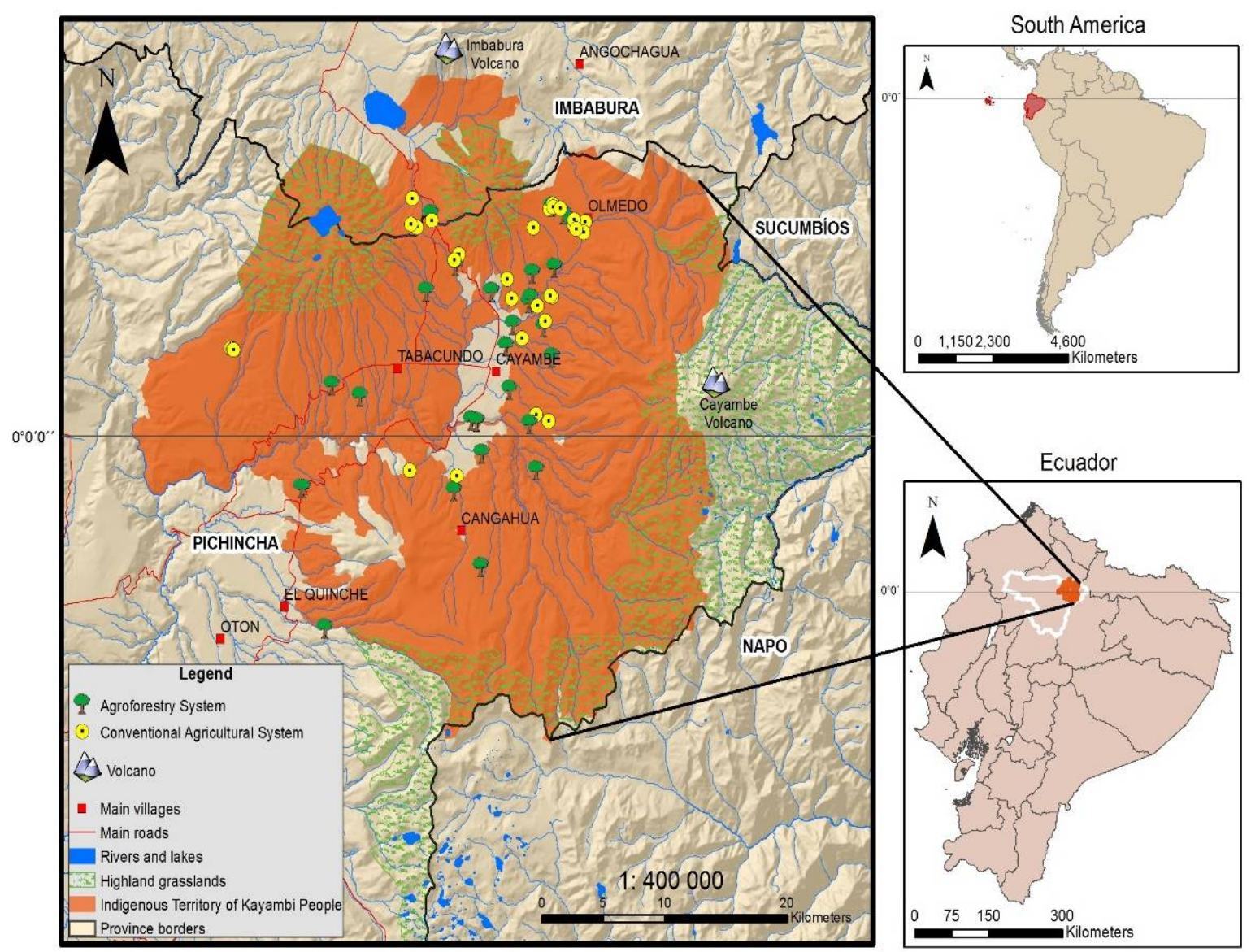

Figure 1. Location of the study area and distribution of the sample farms.

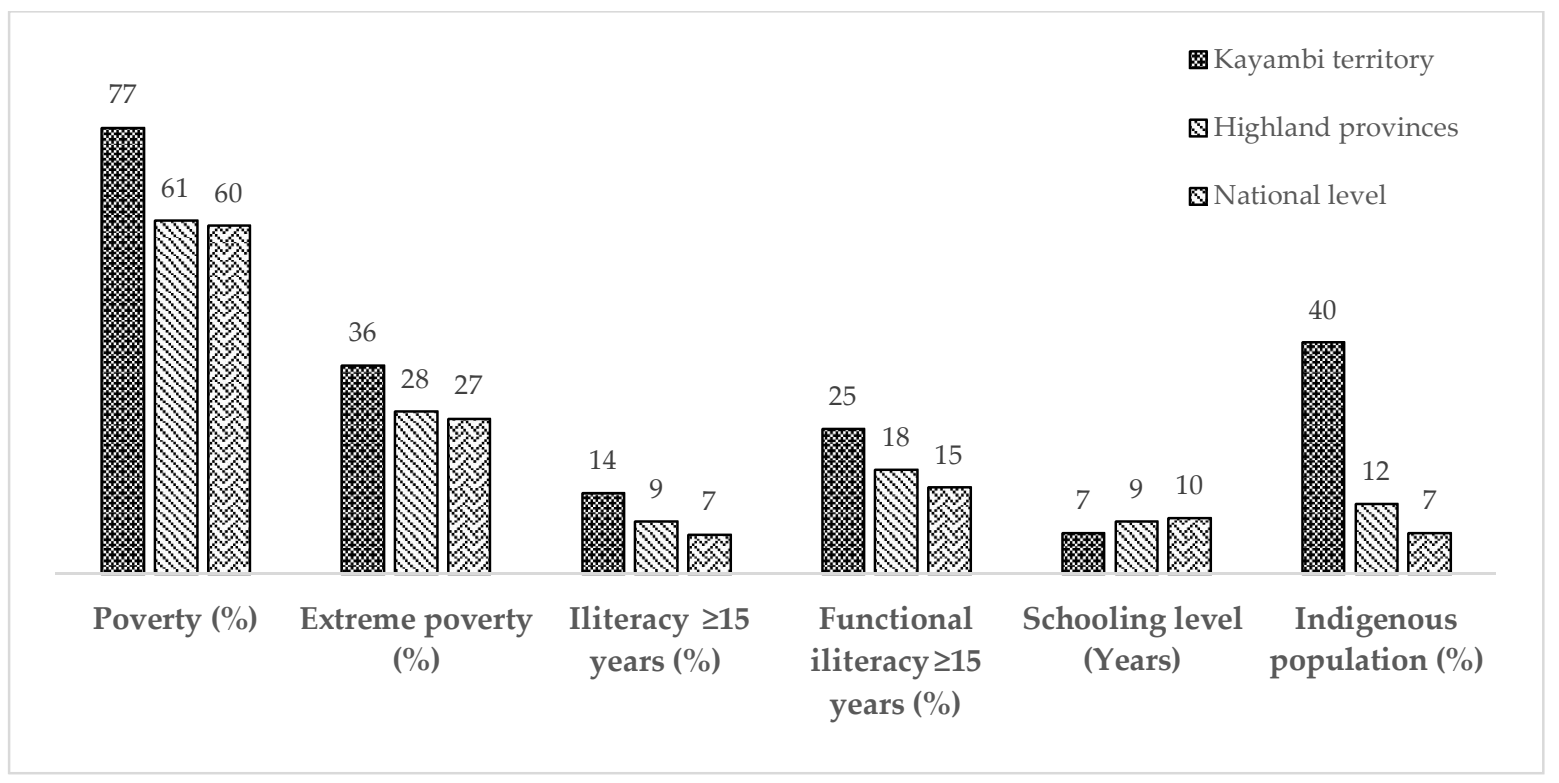

Figure 2. Mean socioeconomic differences among ITKP, highland provinces and national-level, based on Table A1 in the Appendix A and data from Social Indicators System of Ecuador (SIISE)/national population and housing census 2010 [37,38]. 
The study area was located in the highlands of the ITKP at an altitudinal range of 2500 to $3300 \mathrm{~m}$. Areas such as these have special importance in terms of food security and production, at both the local and national levels. Most of the vegetables and tubers consumed locally and in other regions of the country are produced in these areas. Additionally, dairy farming is becoming one of the most expanded activities. Agricultural management in this area is predominantly with permanent and temporary monoculture crops such as pastures, potatoes, maize, broad beans, Andean lupin and vegetables, but in some places alternative management practices such as crop rotation, agroforestry and agrosilvopastoral systems are also implemented. Most of the crops are produced for home consumption and sale in local markets.

Highlands are transition zones with competition between farmland and highland grassland ecosystems, mainly distributed around Cayambe and Imbabura volcanoes, and in the uplands around Olmedo, Cangahua and Tabacundo villages (Figure 1). The highland grasslands are considered a key Andean ecosystem due to their fresh water supply and regulation function. Currently the expansion and intensification of the agriculture and livestock farming activities are the main drivers of highland grassland depletion [39].

The ITKP was selected because the territory fulfilled the main research requirements, which were: the existence of smallholder agroforestry and conventional agricultural farms in highlands, rural livelihoods based mainly on agricultural activities; and importantly, and the willingness of smallholder farmers and indigenous' organizations to participate in the research. The favourable logistics and access to reach and work in the area (road infrastructure; security level and relatively easy access from the capital Quito) were also important considerations in the selection of the study area. The Kayambi People's organisation showed a keen interest in the research and facilitated the access to the territory. The organisation also provided local technicians for logistic and cultural support. Before selecting the ITKP as study area, 15 key informant interviews with smallholder farmers and indigenous leaders were conducted in four highland provinces: Imbabura, Pichincha, Cotopaxi and Chimborazo.

\subsection{Sampling and Data Collection}

A sample of 60 smallholder farms were randomly selected from a total of 633 smallholder farms belonging to the local smallholder farmer organization RESSAK (Network for Food Sovereignty and Solidarity Economy of the Kayambi's territory). These farms are part of approximately 12,000 smallholder farms in the ITKP [40]. The process to select the 60 sample farms was conducted by the main author and three local technicians from the Kayambi People's Organization who identified and chose the farms based on the following criteria: (1) farm size, up to 10 ha [2]; (2) altitude, between 2500 and 4000 m.a.s.l; and (3) the percentage of farm area covered by trees and/or shrubs. Farms with $10 \%$ or more of the area covered by trees and/or shrubs in any spatial arrangement were considered AFS [41], while farms with less than $10 \%$ tree and/or shrub cover were considered CAS.

The AFS and CAS samples were located in upper inter-Andean valleys, foothills and along gorges (Figure 1). AFS sites were difficult to locate since they are a much less common than CAS (which includes mainly annual or seasonal croplands and permanent pastures), and they are scattered throughout the territory. Therefore it was not possible to use villages as a unit, because individual villages had very few households with AFS. This land use pattern is common for the whole Ecuadorian high Andes, where AFS have almost disappeared as a consequence of the influence of colonization, which also changed the production systems [42].

To collect the data, 60 household surveys were conducted mostly with individual farmers, but in some cases with farming couples ( $73 \%$ of the farmers surveyed were women, $10 \%$ were men and the remaining $17 \%$ were couples). Surveys were conducted using semi-structured questionnaires designed to collect primary data about the main biophysical and socioeconomic characteristics of the farming systems (Table A2 in Appendix A). The 60 surveys were conducted directly by the lead author of this paper from December 2015 to May 2016. The detailed questionnaires took an average of between three to four hours to conduct, and the data were directly entered into the database (Table A2 in Appendix A). 
Depending on the farmer's time availability, one or two visits to the farm were sometimes needed to complete the survey. The survey work started with direct observation of the farmland, in a process led by the farmer who was able to explain the main biophysical and socioeconomic characteristics of their farm in person. This was an important step to get the farmer involved in the survey and to improve the interaction between the farmer and the researcher. Many features related to the farmer's household and livelihoods were also highlighted at this step of the survey. In addition, a set of photographs were taken to document each farmer's plot.

The main variables considered in the biophysical component were agrobiodiversity, soil fertility and microclimate conditions inside the farm. Agrobiodiversity was divided into two categories, cultivated biodiversity and associated biodiversity, in order to establish the composition and main characteristics of agrobiodiversity within and between the AFS and CAS. Cultivated biodiversity includes all species, cultivars and breeds introduced and managed by the farmer, which play an important role maintaining food security-sovereignty and enhancing cash income generation. Cultivated biodiversity was analysed in detail through 11 subcategories. In complement, the associated biodiversity category considers the wild plant and animal species commonly found and used in the farming system. The analysis of associated biodiversity was essential to establish its importance for the ecological functionality of the farming system and also to determine its contribution to food security (subsistence) and income generation of smallholders. The method used by the farmers to register and estimate the number of animals and plant species was based on a progressive checklist. The checklist was made as follows: in the first interview the farmer was asked about the species used in the different categories of agrobiodiversity. Every species, cultivars and breeds described by the farmer was registered in the questionnaire matrix (Table A2 in Appendix A) and it represented the starting checklist. In the subsequent interviews, additions were made to the list when the farmer indicated new species, varieties and breeds.

To establish the soil fertility conditions, the main chemical, physical and biological parameters were measured and evaluated through basic soil laboratory analysis (Table A3 in Appendix A). The variables for microclimate conditions inside the farm included temperature, humidity and wind velocity (Table A4 in Appendix A). For the analysis of soil fertility and microclimate conditions, a subsample of 16 farms were chosen randomly from the 60 sample farms and included eight AFS and eight CAS. Only 16 farms were chosen as subsamples due to time and budget limitations. The microclimatic conditions were measured using the Davis Vantage Pro2 micro weather station. The weather station was located strategically in the middle of the farm in order to provide an extensive microclimate measurement. Microclimate measurements were automatically logged every $30 \mathrm{~min}$ during a seven day period in each farm.

For the socioeconomic component, the main variables considered were livelihoods, income levels, agrobiodiversity usage, land tenure and irrigation sources (Table A2 in Appendix A). To categorise and analyse the livelihoods, farmers were asked to describe their main livelihood activities and prioritise them, starting from the activity which generated the highest cash income. The prioritised livelihood activities represented the key data for the identification of the main livelihood categories. Complementary to the livelihood activities analysis, farmers were asked about the contribution of on-farm and off-farm income activities to the household economy. On-farm income activities are related mostly to the commercialisation of farm products and dairy farming, while off-farm income activities are linked to wages obtained from off-farm work, usually related to the construction and fresh cut-flower industries. Based on the basic salary (BS) for Ecuador (1 BS = 375 USD in 2016-2017), incomes were classified according to three levels (high, moderate and low). High income represented more than 1 BS per month, while moderate income was 1 BS, and low income indicates less than $1 \mathrm{BS}$.

For the analysis on how agrobiodiversity contributes to maintain and enhance the smallholder farmers' livelihoods and household economies, the species of cultivated and associated biodiversity were classified in two main use categories: commercial and subsistence-functional species. A species was considered commercial when the species, or a derived product, was used mainly in the provision 
of cash income rather than providing basic household needs (usually food, medicine or fodder). On the other hand, subsistence or functional species were species used by farmers mostly to fulfil basic needs, or species that constitute an intrinsic part of the farming system and support its functionality (usually as pollinators and predator-pest control species). To estimate the ratio of commercial and subsistence-functional species, the farmer was asked about the amount of the production of the species (in \%) used for subsistence (family consumption) or commercial purposes. To define if the species belongs to the subsistence, commercial or both categories, the major proportion was considered, i.e., (a) in the ratio $95 / 05$ (95\% of the production used for subsistence purposes and $05 \%$ for commercial) the species was defined and counted as subsistence species (as in the case of banana passion fruit in Table A2 in Appendix A); (b) in the ratio 05/95, the species was counted as commercial (avocado case in Table A2 in Appendix A); (c) in the case of ratio 50/50, the species was counted equals as subsistence and commercial. To calculate how many subsistence or commercial species are used by the farmer, the species was assigned a value $=1$ in the cases $a$ and $b$. In the case $c$, the species was assigned a value $=0.5$ for counting as subsistence species and 0.5 for commercial. This logic was applied in order to conduct the significance test.

To analyse the land tenure between farming systems, three basic land ownership categories were included, formal, informal and mixed. Formal ownership means that the property rights of the land are officially recognized and protected by the state. In the informal ownership category the property rights are not fully recognized and protected by the state but the access and control of the land are recognized by the community and customary laws. Mixed ownership category includes farmers with some of their farmland as formal and informal.

Finally, to categorise the main irrigation sources, the interview included information related to dependency on rainfall (i.e., rain-fed agriculture), types of irrigation systems, and the methods for water harvesting and storage used by the farmer.

\subsection{Data Analysis}

A comparative analysis approach was applied to analyse the characteristics of the two farming system types. Descriptive statistics (Crosstabs) were used for qualitative variables (livelihood types, land tenure, irrigation sources, income types and levels); and inferential statistical test (Independent-Samples $t$ Test) for quantitative variables (agrobiodiversity and usage; soil fertility parameters and microclimate conditions inside the farms). To analyse the sustainability of the farming systems, key qualitative and quantitative variables were chosen within the biophysical and socioeconomic components of the farming systems. The bulk of the data collected by interviews were based on smallholder farmers' perceptions and observations, except the microclimate and soil data (which was biophysical). The perceptions were related to the main characteristics that maintain and enhance the sustainability of the farming systems.

\section{Results}

\subsection{Biophysical Characteristics within and between Farming Systems}

\subsubsection{Agrobiodiversity}

The results of agrobiodiversity differences between farming systems indicate that there is a statistically significant difference $(p<0.001)$ between AFS and CAS (Table 1$)$. Total agrobiodiversity, formed by the cultivated and associated biodiversity, is $20 \%$ greater in AFS than in CAS. This significant difference, represented by 58 extra species reported in AFS, revels that AFS are more complex and biodiverse systems than CAS (Figure 3a and Table 1). 
Table 1. Agrobiodiversity differences within and between AFS and CAS.

\begin{tabular}{|c|c|c|c|c|c|c|c|c|}
\hline \multirow{2}{*}{ Agrobiodiversity } & \multicolumn{2}{|c|}{ Number of spp. } & \multirow{2}{*}{\multicolumn{2}{|c|}{$\%$ of Difference ${ }^{a}$}} & \multicolumn{2}{|c|}{ Number of Cultivars/Breeds } & \multirow{2}{*}{\multicolumn{2}{|c|}{$\%$ of Difference ${ }^{a}$}} \\
\hline & AFS $^{\mathbf{o}}$ & CAS $^{\circ}$ & & & AFS $^{\mathbf{o}}$ & $\mathrm{CAS}^{\mathrm{o}}$ & & \\
\hline \multicolumn{9}{|l|}{ Cultivated Biodiversity (Subtotal 1) } \\
\hline Trees and shrubs & 32 & 13 & 44 & $* * * *$ & 33 & 13 & 44 & $* * * *$ \\
\hline Legumes and grains & 9 & 8 & 11 & $* * *$ & 21 & 13 & 24 & $* * *$ \\
\hline Tubers and roots & 5 & 4 & 12 & $* *$ & 11 & 7 & 19 & $* *$ \\
\hline Non-tree and shrub fruits & 3 & 2 & 25 & $* * * *$ & 3 & 2 & 26 & $* * * *$ \\
\hline Vegetables & 21 & 11 & 31 & $* * * *$ & 25 & 12 & 34 & $* * * *$ \\
\hline Pastures & 8 & 6 & 12 & ** & 8 & 6 & 12 & ** \\
\hline Medicinal, aromatic and condiment plants & 11 & 4 & 44 & $* * * *$ & 11 & 4 & 45 & $* * * *$ \\
\hline Livestock $^{+}$ & 1 & 1 & 3 & & 1 & 1 & 3 & \\
\hline Minor animals $\ddagger$ & 4 & 3 & 22 & $* * * *$ & 4 & 3 & 23 & $* * * *$ \\
\hline Other (burden animals, ornamental and cultural spp.) & 7 & 3 & 39 & $* * *$ & - & - & - & \\
\hline Subtotal 1 & 102 & 54 & 30 & $* * * *$ & 118 & 62 & 31 & $* * * *$ \\
\hline \multicolumn{9}{|l|}{ Associated Biodiversity (Subtotal 2) } \\
\hline \multicolumn{9}{|l|}{ Wild animals: } \\
\hline Birds & 13 & 11 & 8 & ** & - & - & - & \\
\hline Reptiles & 2 & 2 & 6 & & - & - & - & \\
\hline Amphibians & 2 & 2 & 14 & ** & - & - & - & \\
\hline Mammals & 5 & 4 & 8 & $* *$ & - & - & - & \\
\hline Invertebrates & 30 & 27 & 5 & & - & - & - & \\
\hline Wild animals (Subtotal 2.1) & 52 & 46 & 6 & $* *$ & - & - & - & \\
\hline Wild plants (Subtotal 2.2) & 18 & 13 & 15 & $* * * *$ & - & - & - & \\
\hline Subtotal 2 (Subtotal 2.1 + Subtotal 2.2) & 70 & 59 & 8 & $* * *$ & - & - & - & \\
\hline Total (Subtotal $1+$ Subtotal 2) & 172 & 113 & 20 & $* * * *$ & 118 & 62 & 31 & $* * * *$ \\
\hline
\end{tabular}

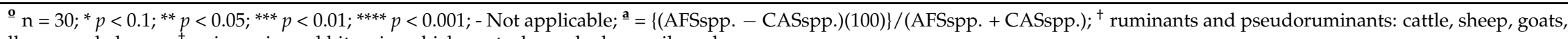
llamas and alpacas; ${ }^{\ddagger}$ guinea pigs, rabbits, pigs, chickens, turkeys, ducks, quails and geese. 


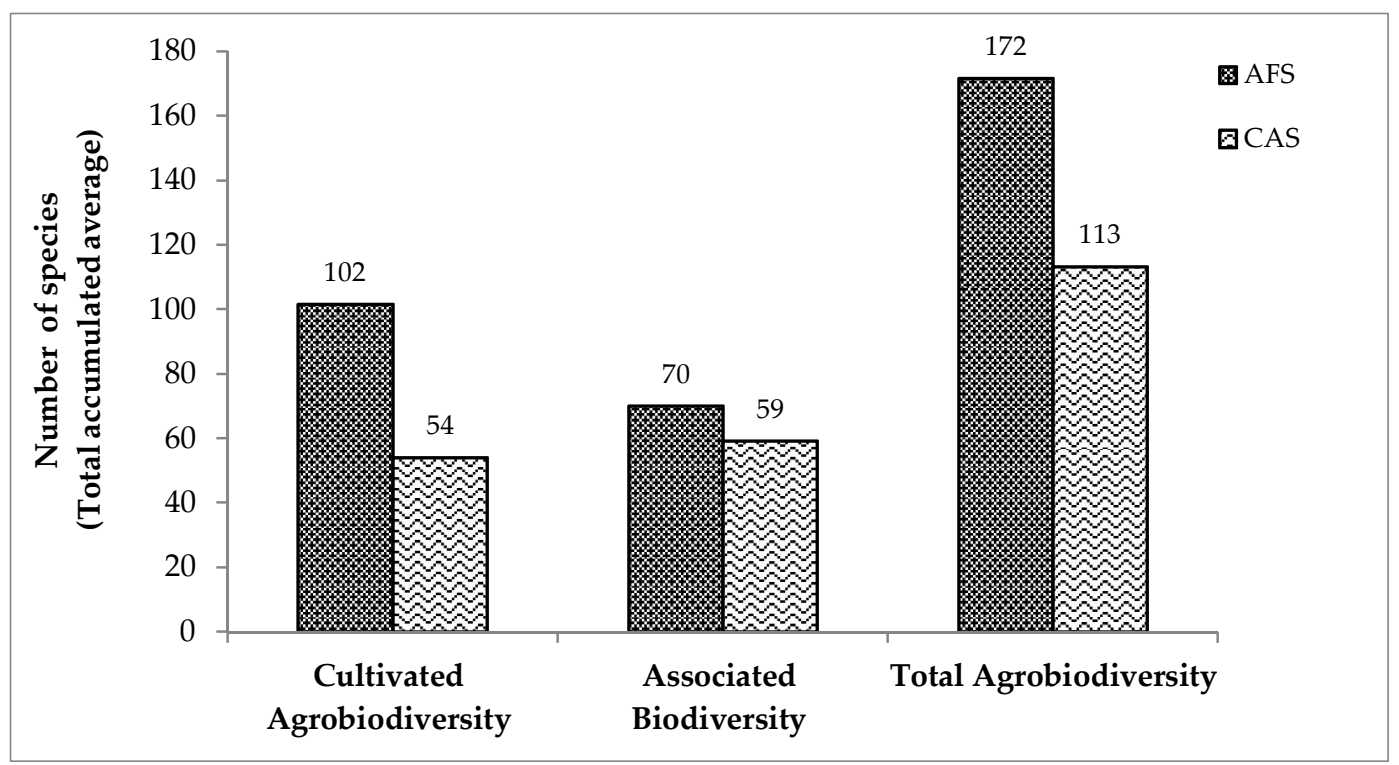

(a)

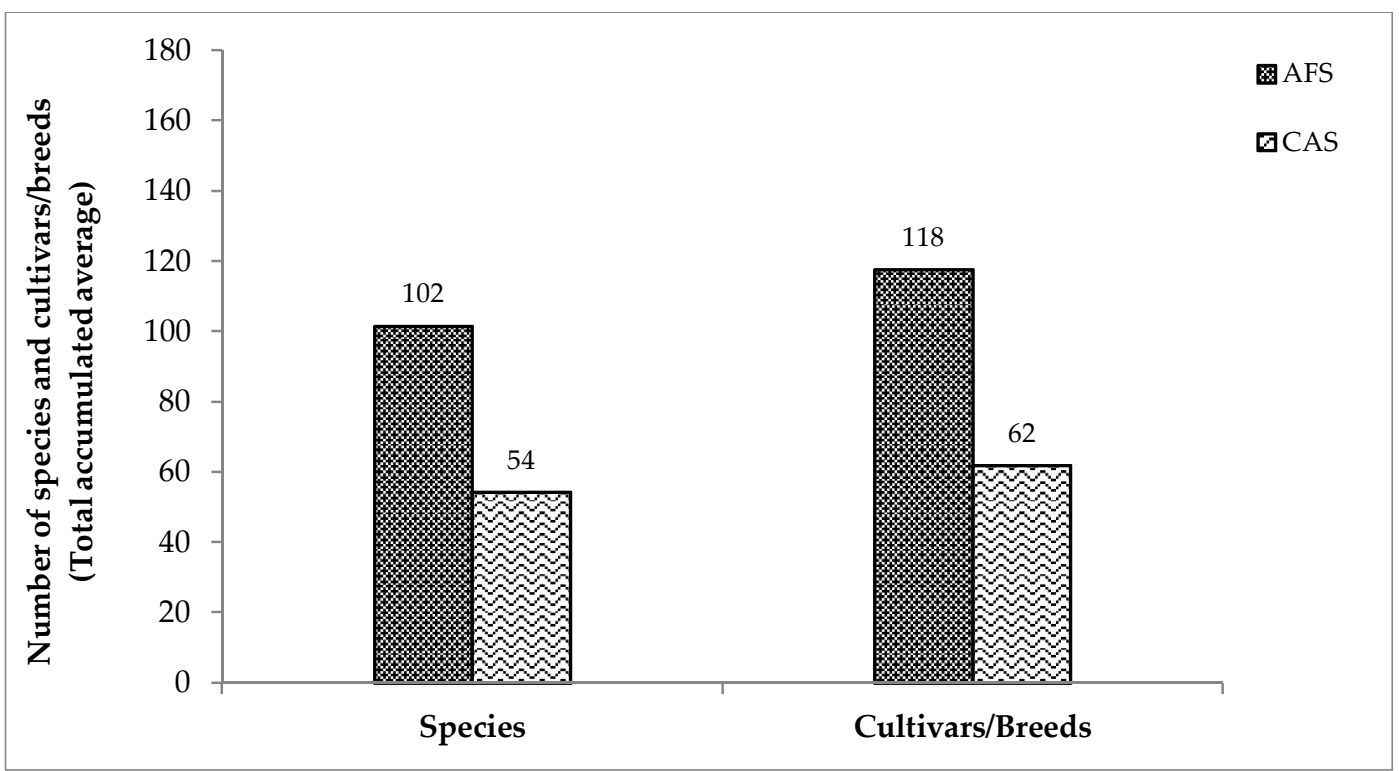

(b)

Figure 3. (a) Agrobiodiversity categories differences between AFS and CAS in number of species; (b) Cultivated agrobiodiversity differences between AFS and CAS in number of species and cultivars/breeds.

There was also a statistically significant difference in the number of species between agrobiodiversity categories (in the same system) and between farming systems ( $p<0.001$ for cultivated biodiversity and $p<0.05$ for associated biodiversity) (Table 1). AFS have both higher cultivated biodiversity and associated biodiversity than CAS (30\% and 8\% higher respectively; Figure 3a and Table 1).

A deeper analysis within agrobiodiversity subcategories shows other important differences between AFS and CAS. In relation to cultivated biodiversity, all AFS subcategories have significantly higher biodiversity than CAS $(p<0.05)$ (Table 1$)$, with the exception of livestock, which has no significant difference $(p>0.05)$. The subcategory with the greatest difference in biodiversity between farming systems is 'Trees and shrubs' ( $44 \%$ more) followed by medicinal, aromatic and condiment plants $(44 \%)$; other species $(39 \%)$ and vegetables $(31 \%)$. 
In order to determine how genetically diverse the cultivated biodiversity subcategories are between the two farming systems, the observed number of cultivars and breeds were also analysed. The results indicate a statistically significant difference in the number of cultivars and breeds between farming systems $(p<0.001)$, with AFS having $31 \%$ greater biodiversity than CAS (Figure $3 \mathrm{~b}$ and Table 1). The most important differences occur in medicinal, aromatic and condiment plants $(45 \%$ more); trees and shrubs (45\%); vegetables (34\%) and non-tree and shrubs fruits (26\%) (Figure 3b and Table 1). There were no significant differences between farming systems in the number of livestock breeds (Table 1).

In the case of associated biodiversity, the wild animals and plants subcategories also presented a statistically significant difference ( $p<0.05$ and $p<0.001$ respectively) (Table 1$)$. AFS had a greater number of species of wild animals $(6 \%)$ and plants $(15 \%)$ than CAS (Table 1$)$. Detailed analysis within the wild animals' subcategory indicates that AFS has a statistically significant higher number species of birds $(8 \%)$, amphibians $(14 \%)$ and mammals $(8 \%)$ than CAS $(p<0.05)$ (Table 1). Although AFS had more species of reptiles $(6 \%)$ and invertebrates $(5 \%)$ than CAS, there was no statistically significant differences (Table 1).

\subsubsection{Soil Fertility}

Soil fertility conditions of AFS were found to be similar to the conditions of CAS, with no statistically significant differences in the results of the subsample of soil fertility parameters (Table A3 in Appendix A). Only phosphorous shows a statistically significant difference between farming systems $(p<0.05)$, indicating that CAS soil has lower levels of phosphorous than AFS, although the levels remained optimal. Considering that phosphorous is one of the three most important macronutrients in soil (nitrogen and potassium being the other two), the lower phosphorous levels shown in CAS (23 ppm) could negatively affect the metabolism of the plants, vegetative growth, root system development, fruit and seed quality, and consequently reduce the potential yields of CAS [43,44]. The soil texture for both AFS and CAS were classified as being the same, sandy loams. Sandy loam soils are considered suitable for most crops, trees and pastures, performing at optimal levels under frequent irrigation and low soil surface pressure to avoid compaction practices [45-48]. The low bulk density values for AFS and CAS (Table A3 in Appendix A), indicate the absence of soil compaction problems and denote optimal conditions of these sandy loam soils to promote favourable development of crops, trees and pastures $[48,49]$. Field capacity measurements also denote an appropriate capacity of AFS and CAS soils to retain water and indicate that the total available water content percent (the portion of water available for plants as a result of the difference between field capacity and wilting point), is also favourable for normal development of crops, pastures and trees. Usually the total available water content for sandy loam soils could reach $20 \%$ (20 g of water $/ 100 \mathrm{~g}$ of soil), presenting some limited access to the available soil water, especially for shallow rooted crops [50,51]. It is important to note that the non-significant differences among most soil parameters were probably due to the small subsample size.

\subsubsection{Microclimate Conditions inside Subsampled Farms}

The results of the microclimate analyses (Table A4 in Appendix A) show that there were no statistically significant differences between AFS and CAS. Considering that variation of microclimate conditions in mountain farming systems, especially temperature and humidity, could promote or restrict the viability of many crops [52-54], it is important to take even small microclimatic differences into account in order to establish which farming system has the most suitable conditions to support agrobiodiversity and smallholder farmers' livelihoods. Results for temperature and wind velocity inside farm indicate more favourable conditions for AFS (Table A4 in Appendix A). Warmer conditions and less influence of wind in the microclimate of AFS, probably due to the greater presence and influence of trees and shrubs, are important aspects to be taken in account in highland farming systems 
where cold, quick temperature fluctuations, and frost could affect agrobiodiversity, especially the viability of some species and cultivars of crops, pastures and animals.

\subsection{Main Socioeconomic Characteristics within and between Farming Systems}

To analyse the socioeconomic dimension of the studied farming systems, the questionnaire (Table A2) included data related to smallholder farmer's livelihoods, income level, main uses of agrobiodiversity, and the main assets to support sustainable livelihoods such as their land tenure situation and irrigation sources.

\subsubsection{Livelihoods}

Figure 4 below shows how the smallholder farmers have classified and prioritised their livelihoods depending on their relevance in terms of which activities generate more cash income for the household economy. The description and prioritisation of the main livelihood activities enabled the identification of seven livelihood categories. Each category contains the main two or three productive activities supporting the cash income and subsistence of the household. The results of Figure 4 denote interesting differences among the livelihoods of smallholder farmers between the two farming systems. Agroforestry farmers show more complex and diversified livelihoods than conventional farmers. Agroforestry households are included in all seven livelihood categories identified in the study, while conventional households are only included in five categories. The cash income activities of agroforestry farmers' livelihoods rely mostly on the commercialisation of farm products $(40 \%)$, while only $17 \%$ of the conventional farmers' livelihoods depend on the same activity. On the other hand, most conventional farmers' livelihoods (37\%) rely mainly on dairy farming in contrast to a marginal $3 \%$ of agroforestry farmers who depend on this activity.

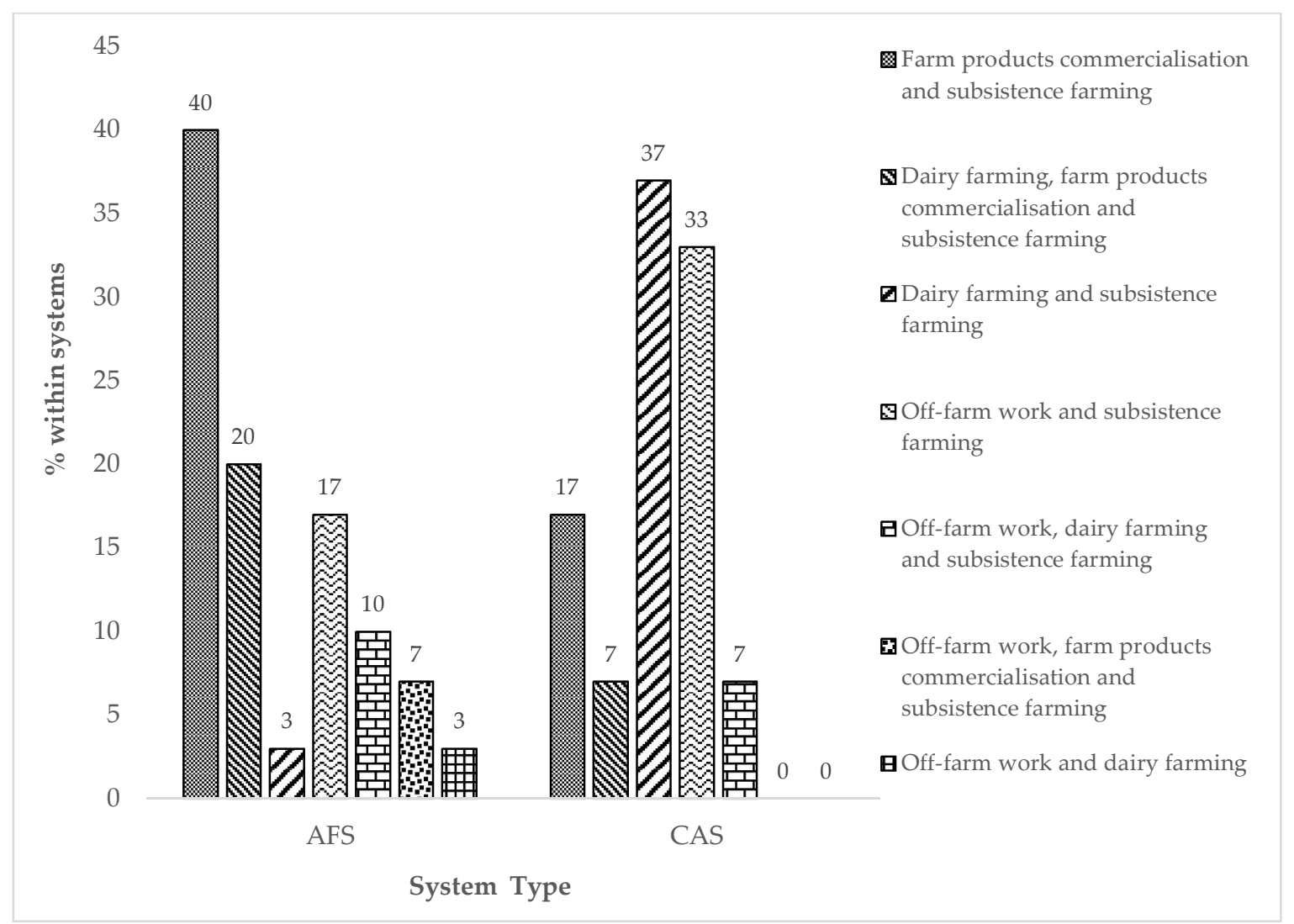

Figure 4. Livelihoods' characterisation and prioritisation by cash income in highland agroforestry and conventional agriculture systems. 
Dairy farming, complemented with commercialisation of farm products, is also an important economic activity for agroforestry farmers, representing $20 \%$ of their livelihood activities, while only $7 \%$ of conventional farmers' livelihoods depend on this combination of activities. Figure 4 also highlights the high dependency of conventional farmers' livelihoods on off-farm work (33\%), while only $17 \%$ of the agroforestry farmers' livelihoods rely exclusively on off-farm work activities. The complexity and diversification of agroforestry livelihoods are denoted also in off-farm work complemented with other productive activities such as dairy farming, farm products' commercialisation and subsistence farming. In that sense, the results indicate that $20 \%$ of agroforestry farmers' livelihoods rely on these activities, while only $7 \%$ of conventional farmers' livelihoods show a similar dependence. It is also important to note that subsistence farming was identified in all livelihoods categories, stressing the importance of this activity in the maintenance of smallholder farmers' livelihoods for both farming system types.

\subsubsection{Income Levels}

The results of Figure 5a,b, shows the farmers' estimations on the contribution of on-farm and off-farm activities to their livelihoods and household economies.

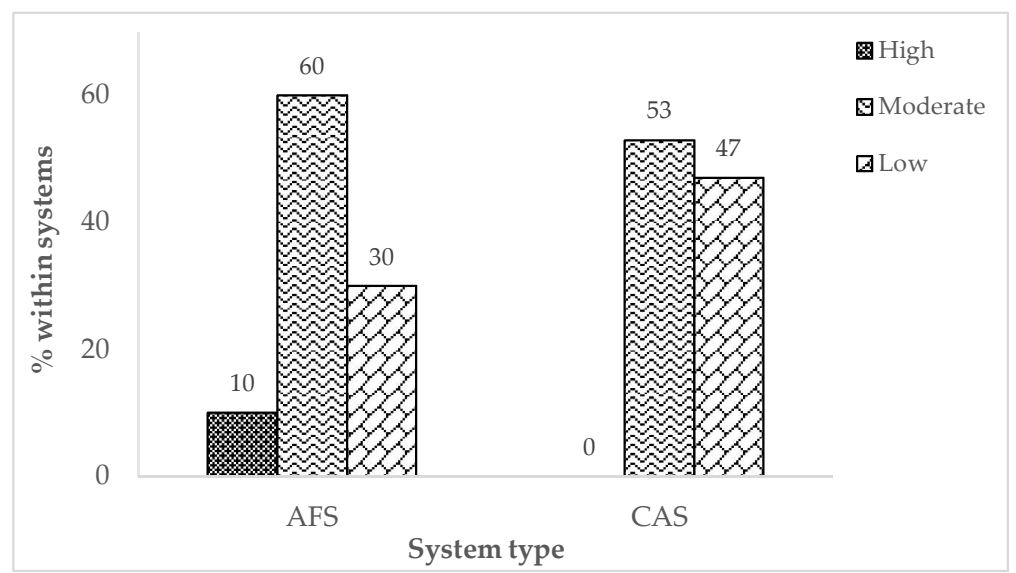

(a)

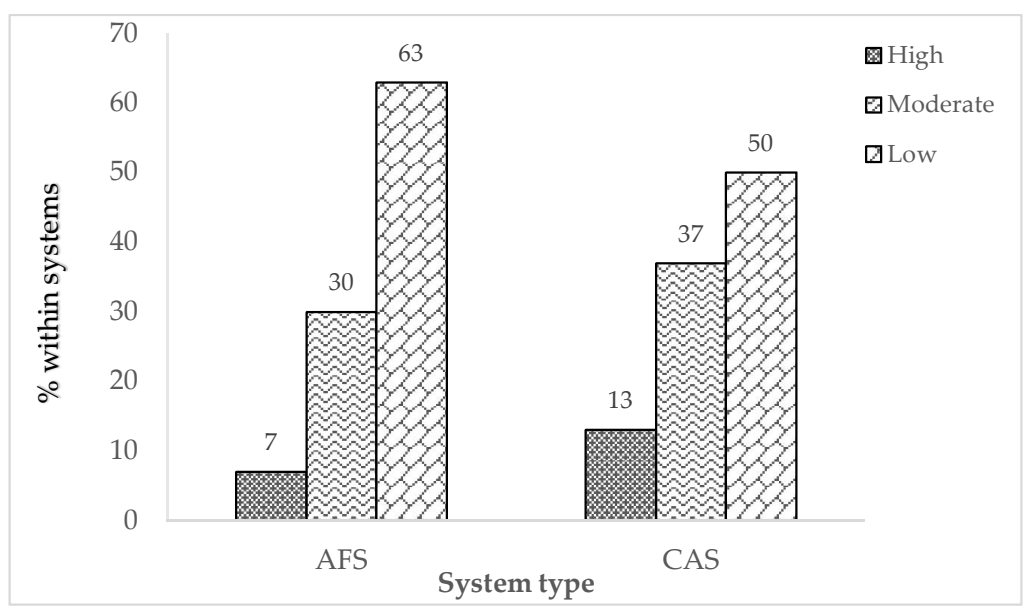

(b)

Figure 5. (a) On-farm income level categorisation by system type; (b) Off-farm income level categorisation by system type.

These results stress the importance of on-farm income for agroforestry farmers and off-farm income for conventional farmers. Figure $5 \mathrm{a}$ indicates that most of agroforestry farmers ( $70 \%)$ estimated that their on-farm incomes were distributed between high and moderate levels $(10 \%$ and $60 \%$ 
respectively). In contrast, all the conventional farmers qualified their on-farm income only as moderate and low level incomes ( $53 \%$ and $47 \%$ respectively).

In the case of the income obtained from off-farm activities, only $7 \%$ and $30 \%$ of agroforestry farmers consider these incomes as high and moderate, respectively. Most agroforestry farmers (63\%) consider the income earned from off-farm work as being low-income levels (Figure 5b). On the other hand, $13 \%$ of conventional farmers estimate their off-farm income levels as being high and 37\% moderate, while the other $50 \%$ perceive these earnings as being low income levels. Consequently, the on-farm income levels reported by agroforestry farmers are greater than the on-farm and off-farm income levels reported by conventional farmers.

\subsubsection{Main Agrobiodiversity Uses}

Considering that agrobiodiversity could play an important role supporting farming systems' functionality, food sovereignty and security, and livelihoods of smallholder farmers, the interviews included a section to record the main uses of agrobiodiversity (Table A2).

In the case of associated biodiversity usage, Table 2 shows that agroforestry farmers use $9 \%$ more species for subsistence farming and farming system functionality than conventional farmers $(p<0.05)$. In addition to the usage of associated biodiversity species, commercialisation of wild animals and plants does not represent an important income generation activity for smallholders' livelihoods in either of the studied farming systems, with no statistically significant difference (Table 2).

The results of Table 2 indicate that the role of agrobiodiversity in enhancing the livelihoods of smallholder farmers is more relevant for agroforesters than conventional farmers, i.e., through the maintenance of household economies and the main subsistence needs (food, medicine and fodder), and at the same time supporting the ecological functionality of the farming systems.

\subsubsection{Land Tenure and Irrigation Sources}

An analysis of land tenure, water availability, and irrigation sources was included in this study because farmland and water are considered the main assets of production, and at the same time the access and control of these resources constitute common limiting factors affecting the livelihoods of smallholder farmers [14,15].

Although all the farmers included in this study sample have access to private farmland (an average of $3 \mathrm{ha}$ ), the land tenure situation between farming systems reveals some interesting differences. Figure 6 shows the land tenure status of smallholder farmers and indicates more favourable conditions for agroforestry farmers than for conventional farmers. Most agroforesters $(60 \%)$ are formal owners (when farmland is formally recognised by the state), while only $27 \%$ of conventional farmers have the same ownership status. On the other hand, $30 \%$ of conventional farmers are informal owners (when farmland is not formally recognised by the state but it is recognized by the community through customary rights) compared to only $7 \%$ of agroforesters in the same category. Mixed land ownership (when some part of the farmland is formally recognised by the state and another part recognised only by the community) is also higher in CAS (43\%) than in AFS (33\%).

In the case of water availability and irrigation sources, Figure 7 describes the seven irrigation categories found in the study and their distribution between farming systems. Results indicate more diversified irrigation sources for agroforesters (six categories) than conventional farmers (four categories). Agroforestry farmers are less dependent on rain-fed methods (29\%) than conventional farmers (56\%). Most agroforesters have greater access to surface water as part of a communal irrigation system with sprinklers (50\%) than conventional farmers ( $40 \%)$. From the point of view of water-use efficiency and adaptability to climate change and variability, the farmers with access to surface water through communal irrigation systems-which use sprinklers and reservoirs-certainly are the best prepared farmers to deal with these issues. A higher percentage of agroforesters are included in this category $(17 \%)$ compared to conventional farmers $(3 \%)$. 
Table 2. Main agrobiodiversity uses differences within and between AFS and CAS.

\begin{tabular}{|c|c|c|c|c|c|c|c|c|}
\hline \multirow{2}{*}{ Agrobiodiversity } & \multicolumn{2}{|c|}{ Number of Subsistence/Functional spp. } & \multicolumn{2}{|c|}{$\%$ of Difference ${ }^{a}$} & \multicolumn{2}{|c|}{ Number of Commercial spp. } & \multirow{2}{*}{\multicolumn{2}{|c|}{$\%$ of Difference }} \\
\hline & & & & & & & & \\
\hline \multicolumn{9}{|l|}{ Cultivated biodiversity (Subtotal 1) } \\
\hline Trees and shrubs & 31 & 12 & 43 & $* * * *$ & 1 & 0 & 89 & * \\
\hline Legumes and grains & 7 & 7 & 1 & & 2 & 1 & 41 & ** \\
\hline Tubers and roots & 4 & 3 & 9 & & 1 & 0 & 40 & * \\
\hline Non-tree and shrub fruits & 3 & 2 & 23 & $* * *$ & 0 & 0 & 52 & $* *$ \\
\hline Vegetables & 12 & 9 & 16 & $* *$ & 8 & 2 & 59 & $* * * *$ \\
\hline Pastures & 8 & 6 & 10 & $* *$ & 0 & 0 & 100 & \\
\hline Medicinal, aromatic and condiment plants & 8 & 4 & 34 & $* * * *$ & 3 & 0 & 91 & ** \\
\hline Livestock $^{+}$ & 1 & 0 & 15 & & 1 & 1 & 7 & \\
\hline Minor animals $\ddagger$ & 3 & 2 & 18 & $* * *$ & 1 & 0 & 38 & $* *$ \\
\hline Other (burden animals, ornamental \& cultural spp.) & 7 & 3 & 39 & $* * *$ & 0 & 0 & 100 & \\
\hline Subtotal 1 & 84 & 49 & 26 & $* * * *$ & 17 & 5 & 56 & $* * * *$ \\
\hline \multicolumn{9}{|l|}{ Associated biodiversity (Subtotal 2) } \\
\hline \multicolumn{9}{|l|}{ Wild animals: } \\
\hline Birds & 13 & 11 & 8 & $* *$ & 0 & 0 & 0 & \\
\hline Reptiles & 2 & 2 & 6 & & 0 & 0 & 0 & \\
\hline Amphibians & 2 & 2 & 14 & $* *$ & 0 & 0 & 0 & \\
\hline Mammals & 5 & 4 & 8 & $* *$ & 0 & 0 & 0 & \\
\hline Invertebrates & 30 & 27 & 5 & & 0 & 0 & 100 & \\
\hline Wild animals (Subtotal 2.1) & 52 & 46 & 6 & $* *$ & 0 & 0 & 100 & \\
\hline Wild plants (Subtotal 2.2) & 18 & 13 & 15 & $* * * *$ & 0 & 0 & 100 & \\
\hline Subtotal 2 (Subtotal $2.1+$ Subtotal 2.2) & 70 & 59 & 8 & $* * *$ & 0 & 0 & 100 & \\
\hline Total (Subtotal $1+$ Subtotal 2) & 154 & 108 & 17 & $* * * *$ & 17 & 5 & 56 & $* * * *$ \\
\hline
\end{tabular}

${ }^{\mathbf{o}} \mathrm{n}=30 ;{ }^{*} p<0.1 ;{ }^{* *} p<0.05 ;{ }^{* * *} p<0.01{ }^{* * * *} p<0.001 ;-$ Not applicable; ${ }^{\mathbf{a}}=\{($ AFSspp. - CASspp. $)(100)\} /\left(\right.$ AFSspp. + CASspp.); ${ }^{\dagger}$ ruminants and pseudoruminants: cattle, sheep, goats, llamas and alpacas; ${ }^{\ddagger}$ guinea pigs, rabbits, pigs, chickens, turkeys, ducks, quails and geese. 


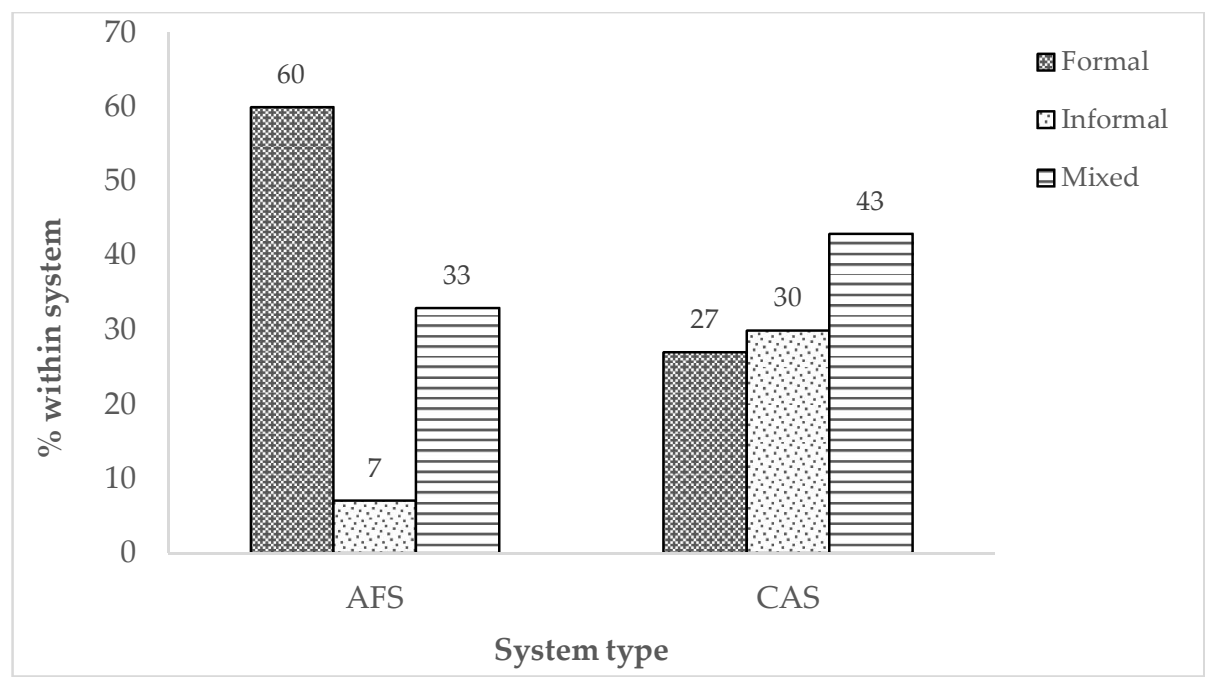

Figure 6. Land tenure categorisation by system type.

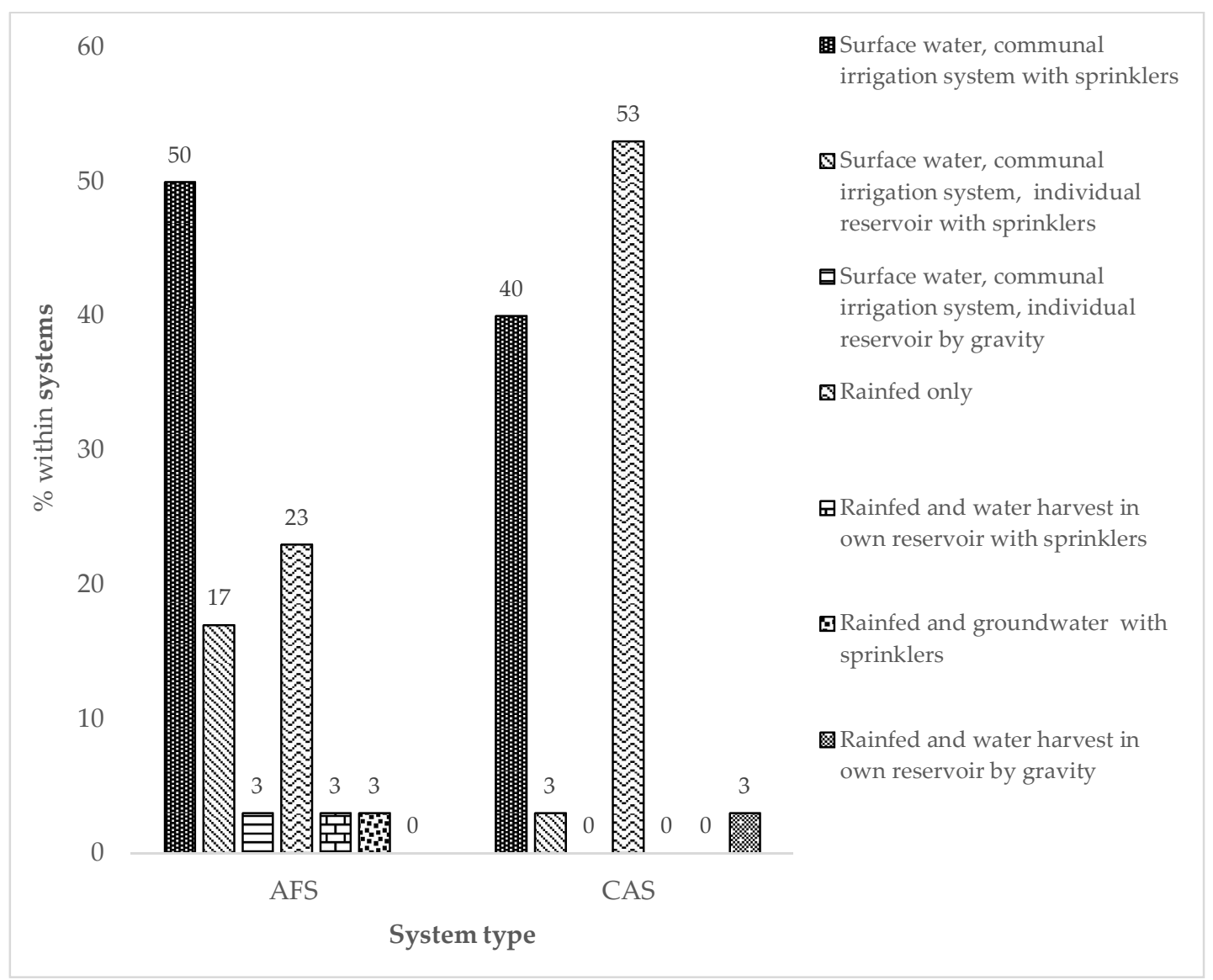

Figure 7. Irrigation sources categorisation by system type.

\section{Discussion}

The results of this paper provide important evidence to inform understanding of how the basic biophysical and socioeconomic features of two farming system types (AFS and CAS) could contribute to support sustainable livelihoods of smallholder farmers. 
Among the biophysical features included in this study, the higher levels of agrobiodiversity estimated for AFS represent one of the most interesting-although unsurprising-findings. In reviewing the literature, many papers have stressed the intrinsic value of agrobiodiversity to sustain rural livelihoods and maintain important farming system services. According to the literature, agrobiodiversity plays a key role in providing better food access; improved diets; reduced malnutrition (a major problem in the study area); and to support more sustainable food systems [55-58]. Complementing this, the greater levels of agrobiodiversity in a system contributes to enhanced delivery of some important regulatory and provisioning ecosystem services such as pest and disease control, pollination, microclimate control, yield stability and efficiency, primary production, provision of habit, and nutrient and water cycling. Considering these benefits, the results of this study support the increasing body of evidence that agrobiodiversity provides better environmental and socioeconomic opportunities to sustain livelihoods of smallholder farmers, especially in the context of global change $[59,60]$. Therefore the higher levels of agrobiodiversity found in AFS represent an important farming system asset to support the natural capital (natural resource base) [61,62] of agroforesters' livelihoods. In addition, the benefits of greater agrobiodiversity levels of AFS are also related to the greater use of subsistence-functional and commercial species, especially in the case of cultivated biodiversity shown by agroforesters (Table 2). Greater availability and usage of subsistence-functional species support agroforesters' livelihoods with better opportunities to sustain food security-sovereignty and farming system services (natural capital). Complementing this, the greater use of commercial species by agroforesters (Table 2) diversifies their economic incomes and provides better support to the financial-economic capital.

Despite the lack of similar studies conducted in the highland region of Ecuador, the agrobiodiversity results of this study are aligned with results of other studies on smallholder farmers carried out in the region. The estimated levels of cultivated agrobiodiversity presented in this study follow a similar tendency found by Oyarzun et al. [23] in the Central Highlands of Ecuador. These authors reported highly cultivated agrobiodiversity levels in smallholdings, showing a positive relationship between the number of on-farm cultivated species and the number of species and products destined for home consumption. The study indicates that smallholdings with high agrobiodiversity levels tend to consume more on-farm food items than the households living in low agrobiodiversity farms. The results of the main agrobiodiversity usages also coincides with well-established assumptions of other studies $[63,64]$ which indicate that smallholder farmers in the Andes of Ecuador dedicate most of their production to subsistence needs.

Although the greater availability and usage of subsistence-functional species found in AFS do not directly indicate their specific contribution to support sustainable livelihoods and farming systems' functioning, these findings highlight the potential of these species to be developed as 'Agroforestry Tree Products (AFTP)' [58] for sustainable and multifunctional farming systems (especially in the case of indigenous and exotic trees and shrubs). AFTP are new and highly nutritious crops (originated from the domestication of useful trees), which could enhance the production and the socioeconomic and environmental sustainability of smallholder farming systems [58]. Such an approach could be relevant for the study area and Andean Highlands.

For the socioeconomic features considered in this study (such as livelihood composition, income levels, agrobiodiversity usages, land tenure and irrigation sources), the findings show a greater potential for agroforesters to support sustainability than conventional farmers. The composition of livelihoods prioritised by smallholder farmers based on the activities which generate the main cash incomes denote the livelihood portfolios used by farmers to improve their incomes and reduce socioeconomic and environmental risks. Although the livelihood portfolios of agroforesters and conventional farmers are quite similar, there are remarkable differences among on- and off-farm activities, which could provide interesting inputs for sustainability analysis. The more diverse agroforesters' livelihoods portfolios represent an important advantage to reduce socioeconomic and environmental vulnerability and risk (such as market fluctuations, disease, natural hazards and climate 
extremes) especially in the context of global change. In addition, although the levels of dependence on off-farm activities between the livelihoods of agroforesters and conventional farmers are similar, the off-farm portfolios of agroforesters include complementary on-farm activities mainly oriented to improve their cash incomes and support food security. For example: off-farm work + dairy farming; or off-farm work + farm product commercialization + subisistence farming; or off-farm work + dairy farming + subsistence farming (Figure 4). By contrast, the on-farm activities included in off-farm portfolios of conventional farmers are mostly focused on staple food supply through subsistence farming (Figure 4). Therefore, the off-farm portfolio composition of agroforesters in this study could be seen as an advantage to enhance sustainable livelihoods since these activities could give extra support to their financial capital component. In general, off-farm portfolios of smallholder farmers are characterised by activities that promote extra cash income $[65,66]$. These are often based on temporary or permanent migration to work as hired labour, which is one of the most common strategies for livelihood diversification $[60,61,65,66]$. In this context, the off-farm portfolios of smallholder farmers in this study are also characterised by temporary or permanent migration whereby typically the male household head migrates to other areas to be employed as a low cost worker in the building sector (especially in urban areas) or in the expanding fresh-cut flower industry [67-71]. This explains why most of the household heads interviewed in this study were women.

The less dependence of agroforesters' livelihoods on off-farm activities and off-farm income differs from the findings of other studies which estimate that the majority of smallholdings in Ecuador, with more prevalence in highlands, depend mainly on off-farm activities and incomes [72] (the case of conventional farmers' households in this study).

The differences found in land tenure conditions between agroforesters and conventional farmers also provide an interesting angle to discuss the sustainability of the studied farming systems. According to the literature on the topic, the land tenure status may represent one of the most decisive issues influencing other socioeconomic features included in the study. The more secure land tenure situation for most agroforesters in this study, could enhance farmers' opportunities to invest and increase production [73], while at the same time contributing to livelihood diversification and enhancing sustainability $[66,74]$. By contrast, the land tenure insecurity indicated by most of the conventional farmers puts property rights at risk due to other potential land claimants or even through eviction [74]. In addition, insecure land tenure affects the farmers' assets to provide food sovereignty and security to their households, restricting farmer's investments in important assets for production such as irrigation systems; farm equipment and infrastructure; credits and financial assistance [73].

The greater diversification of irrigation sources and the lesser dependency on rain-fed agriculture found in AFS could have positive effects on the productivity of the system, and most likely reduces the vulnerability of these systems to climate variability and change, placing agroforesters in a better position to maintain and enhance their livelihoods than conventional farmers. Therefore, smallholder farmers-with clear property rights-would be more motivated to adopt alternative production approaches and make greater investments in productive assets (such as trees for agroforestry practices; increment on agrobiodiversity, improvements to farm equipment and infrastructure; and implementation of irrigation systems) in order to intensify the agricultural activities which enhance the self-sufficiency of their livelihoods (characterised mainly by economic and food security/sovereignty).

The socioeconomic findings of this study are also in line with those of previous studies, which consider AFS to be one of the land use practices with enormous potential to enhance sustainable livelihoods and promote the adaptation and mitigation of smallholder farmers' farming systems to climate change and variability [26,41,75-77].

\section{Conclusions}

This study provides qualitative and quantitative evidence to suggest that the highland agroforestry farming systems in the ITKP provide more favourable biophysical and socioeconomic conditions than conventional farming systems to maintain and enhance sustainable livelihoods of smallholder farmers. 
Among all the factors analysed, the statistically significant difference in agrobiodiversity species between farming systems - with AFS having more agrobiodiversity than CAS-was one of the most important findings. Other interesting findings were the differences found in the numbers of cultivars/breeds and commercial and subsistence/farming system functioning species used by farmers. AFS could be considered as more genetically diversified farming systems than CAS. The greater levels of agrobiodiversity found in AFS, and especially in the case of the cultivated biodiversity (species, cultivars and breeds), indicate that agroforesters have better socioeconomic and environmental assets to sustain their livelihoods and households than conventional farmers.

All the socioeconomic aspects included in this study, especially livelihood composition; on-and off-farm income levels and agrobiodiversity usages, indicate major advantages of AFS to support sustainable smallholder farmers' household incomes and livelihoods compared to CAS.

Additional studies using quantitative methods could be done to complement the findings of this study. For example: in the case of agrobiodiversity, on-farm inventories during different crop seasons could be done to establish a more precise number of cultivated and wild species used by farmers. In the case of some socioeconomic variables such as agrobiodiversity usages and income levels, it could be interesting to know how the commercialisation of agrobiodiversity economically contribute to improve the incomes levels and if the improvements of income levels and land tenure status contributes to enhancing sustainability through the direct investments on productive assets (such as infrastructure, equipment, technology and capacitation). An analysis of the vulnerability and resilience of different farming system types to climatic variability and change also is needed in order to have a complete appraisal of the sustainability of smallholders' livelihoods in the global change context. These issues were beyond the aims of current study and could be considered for further research.

The methods and findings of this research could be considered as an important contribution and reference point for the scarce, but increasing body of knowledge comparing traditional agroforestry and conventional agriculture systems in the tropical highlands. Considering the limited knowledge and geographical expansion of agroforestry practices in the study area and Ecuadorian highlands in general, the results of this study could enhance the initiatives which promote trees and agroforestry practices as essential components to improve the livelihoods and sustainability of smallholder farmers, and contribute to the increasing agroecological approach implemented at local, regional and global levels to deal with the global change process. The results of this study suggest that AFS should be promoted in Ecuadorian highlands due to the socioeconomic and environmental advantages to support and enhance sustainable livelihoods.

Finally, more multidisciplinary research is needed in the High Andes in order to understand the characteristics of the different farming systems and the strategies implemented by the farmers to support sustainable livelihoods in the context of local, regional and global change.

Acknowledgments: This study was supported by the Ecuadorian people and government through a scholarship from the National Secretariat of Higher Education, Science, Technology and Innovation (SENESCYT). We thank the University of Helsinki and the Viikki Tropical Resources Institute (VITRI) for the academic and extra financial support for the field work. We are grateful to the Kayambi People Organization and all the farmers who contributed and shared their traditional knowledge. A special recognition to the Geographer Anaí Bustos for the elaboration of the study area map.

Author Contributions: Raúl Córdova conceived the paper, designed the methods and carried out the data collection. Raúl Córdova and Nicholas J. Hogarth analysed the data. Raúl Córdova wrote the main draft and Nicholas J. Hogarth and Markku Kanninen edited and contributed to the interpretation of results and discussion.

Conflicts of Interest: The authors declare no conflict of interest.

\section{Appendix A}


Table A1. Socioeconomic and demographic data of the Indigenous Territory of Kayambi People.

\begin{tabular}{|c|c|c|c|c|c|c|c|c|c|}
\hline Province & Canton & Parish & $\begin{array}{c}\text { Total } \\
\text { Population }\end{array}$ & Poverty * (\%) & $\begin{array}{c}\text { Extreme } \\
\text { Poverty * }(\%)\end{array}$ & $\begin{array}{c}\text { Illiteracy } \geq 15 \\
\text { Years (\%) }\end{array}$ & $\begin{array}{c}\text { Functional Illiteracy } \\
\geq 15 \text { Years }(\%)\end{array}$ & $\begin{array}{c}\text { Schooling } \\
\text { Level (Years) }\end{array}$ & $\begin{array}{c}\text { Indigenous } \\
\text { Population (\%) }\end{array}$ \\
\hline \multirow[t]{3}{*}{ Imbabura } & Ibarra & Angochagua & 3263 & 92 & 69 & 29 & 42 & 4 & 92 \\
\hline & Otavalo & San Pablo & 9901 & 72 & 39 & 19 & 29 & 7 & 41 \\
\hline & & Gonzalez Suarez & 5630 & 84 & 39 & 16 & 26 & 7 & 72 \\
\hline \multirow[t]{12}{*}{ Pichincha } & Quito & El Quinche & 16056 & 54 & 18 & 6 & 15 & 9 & 6 \\
\hline & Cayambe & Cayambe & 50829 & 53 & 21 & 7 & 15 & 9 & 17 \\
\hline & & Ascazubi & 5050 & 63 & 21 & 7 & 17 & 8 & 7 \\
\hline & & Cangahua & 16231 & 95 & 64 & 24 & 40 & 5 & 81 \\
\hline & & Olmedo-Pesillo & 6772 & 89 & 57 & 17 & 26 & 6 & 81 \\
\hline & & Otón & 2766 & 93 & 40 & 17 & 32 & 5 & 20 \\
\hline & Pedro Moncayo & Sata Rosa de Cuzubamba & 4147 & 81 & 28 & 9 & 19 & 7 & 4 \\
\hline & & Tabacundo & 16403 & 62 & 23 & 8 & 16 & 8 & 17 \\
\hline & & La Esperanza & 3986 & 71 & 30 & 7 & 17 & 7 & 32 \\
\hline & & Malchinguí & 4624 & 71 & 21 & 13 & 26 & 7 & 2 \\
\hline & & Tocachi & 1985 & 82 & 46 & 12 & 24 & 6 & 5 \\
\hline & & Tupigachi & 6174 & 95 & 46 & 17 & 25 & 6 & 73 \\
\hline \multirow[t]{3}{*}{ Napo } & Chaco & Oyacachi & 620 & 79 & 23 & 14 & 24 & 7 & 93 \\
\hline & & Total population ITK & 154437 & - & - & - & - & - & - \\
\hline & & Mean & - & 77 & 36 & 14 & 25 & 7 & 40 \\
\hline
\end{tabular}

* Poverty and extreme poverty based on unsatisfied basic needs index (NBI). Source: Social Indicators System of Ecuador (SIISE) and data from the national population and housing census $2010[37,38]$. 
Table A2. Questionnaire for the main biophysical and socioeconomic characteristics of highland farming systems.

\begin{tabular}{|c|c|c|c|c|}
\hline \multicolumn{5}{|c|}{ (Printable Format Sample 1) } \\
\hline \multicolumn{5}{|l|}{ 1. General Information } \\
\hline Survey No: & & Date: & & \\
\hline \multicolumn{5}{|l|}{ Farmer name: } \\
\hline Province: & Canton: & & Community: & \\
\hline Altitude (m.a.s.l): & Coordinates: & & & Slope (\%): \\
\hline \multicolumn{5}{|l|}{ 2. Main Agroecosystem aspects: } \\
\hline \multirow{2}{*}{ Agroecosystem type } & Agroforestry & $\mathbf{x}$ & & \\
\hline & Conventional & & & \\
\hline Main land use & Area (ha) & Age (years): & Remarks & \\
\hline Crops and trees/shrubs & 0.5 & 16 & Slow-forming terraces & \\
\hline \multicolumn{5}{|l|}{ Pastures and trees/shrubs } \\
\hline \multicolumn{5}{|l|}{ Only crops: (monocrops/many crops/rotating crops) } \\
\hline \multicolumn{5}{|l|}{ Only pastures: (planted pastures, meadows) } \\
\hline \multicolumn{5}{|c|}{ Others, specify: (grazing communal area, own or communal native forest remnants) } \\
\hline Fallow plot in other locality & 1 & 2 & & \\
\hline Total & 1.5 & & & \\
\hline \multicolumn{5}{|l|}{ 3. Main socioeconomic aspects: } \\
\hline \multirow{2}{*}{ Ethnic group } & Indigenous & $\mathrm{x}$ & Nationality/People: & Kichwa/Kayambi \\
\hline & Mestizo & & & \\
\hline \multicolumn{5}{|l|}{ Main livelihoods description: } \\
\hline \multicolumn{5}{|c|}{ Garage (husband and older daughter), agroecological production and commercialisation of fruits, } \\
\hline \multicolumn{5}{|c|}{ vegetables and minor animals ( whole family), food sale at weekends (younger daughter) } \\
\hline \multicolumn{5}{|l|}{ Main cash income livelihoods: } \\
\hline \multicolumn{5}{|l|}{ 1.- Garage } \\
\hline 2.- Commercialisation of agroecological products & & & & \\
\hline
\end{tabular}


Table A2. Cont.

\begin{tabular}{|c|c|c|c|c|}
\hline \multicolumn{5}{|c|}{ (Printable Format Sample 1) } \\
\hline \multicolumn{5}{|l|}{ Income categorisation: } \\
\hline & & Low $(<375$ USD) & Moderate (=375 USD) & High (>375 USD) \\
\hline On-farm income & & & $\mathrm{x}$ & \\
\hline Off-farm income at household level & & & $\mathrm{x}$ & \\
\hline Irrigation sources & & & & Remarks \\
\hline Irrigation system & $\mathrm{x}$ & Type & Sprinklers in a communal system & In dry seasons: 3 hours every 2 days per week. \\
\hline Rainfed only & & Period/months & & \\
\hline Reservoir & $\mathrm{x}$ & Capacity $\left(\mathrm{m}^{3}\right)$ & 50 & 2 individual reservoirs \\
\hline \multicolumn{5}{|l|}{ Other/specify: } \\
\hline Land tenure & & Remarks & & \\
\hline Formal owner & $\mathrm{x}$ & Whole farming la & ate recognized & \\
\hline \multicolumn{5}{|l|}{ Informal owner } \\
\hline \multicolumn{5}{|l|}{ Other/specify: } \\
\hline \multicolumn{5}{|c|}{ (Printable Format Sample 2) } \\
\hline \multicolumn{5}{|l|}{ 4. Agrobiodiversity } \\
\hline \multicolumn{5}{|l|}{ Cultivated biodiversity } \\
\hline \multicolumn{5}{|l|}{ Forestry component } \\
\hline \multicolumn{5}{|l|}{ Trees and shrubs (included fruit species): } \\
\hline Species & Cultivars/Breeds & Subsistence Use & Commercial Use & Subst./Comerc. \% \\
\hline \multirow{5}{*}{ Aguacate/Avocado/Persea americana Mill. } & Guatemalteco & $\mathrm{x}$ & $\mathrm{x}$ & $05 / 95$ \\
\hline & Black & $x$ & $x$ & $05 / 95$ \\
\hline & National Black & $x$ & $x$ & $05 / 95$ \\
\hline & National Green & $x$ & $x$ & $05 / 95$ \\
\hline & Jassh & $x$ & $x$ & $05 / 95$ \\
\hline
\end{tabular}


Table A2. Cont.

\begin{tabular}{|c|c|c|c|c|}
\hline \multicolumn{5}{|c|}{ (Printable Format Sample 1) } \\
\hline \multicolumn{5}{|l|}{ Crops component } \\
\hline \multicolumn{5}{|l|}{ Grains and legums: } \\
\hline \multirow{4}{*}{ Maíz/Corn/Zea mays L. } & Morocho & $\mathrm{x}$ & & \\
\hline & Popcorn & $\mathrm{x}$ & & \\
\hline & Black & $\mathrm{x}$ & & \\
\hline & White and soft & $\mathrm{x}$ & & \\
\hline \multicolumn{5}{|l|}{ Tubers and roots: } \\
\hline \multirow{6}{*}{ Potato/Solanum tuberosum L. } & Violet & $\mathrm{x}$ & & \\
\hline & Chola & $\mathrm{x}$ & & \\
\hline & Super chola & $\mathrm{x}$ & & \\
\hline & White Chaucha & $x$ & & \\
\hline & Unique & $\mathrm{x}$ & & \\
\hline & Curipampa & $\mathrm{x}$ & & \\
\hline \multicolumn{5}{|c|}{ Fruits (other fruits different from trees and shrubs: } \\
\hline Taxo/banana passionfruit/Passiflora sp. & & $x$ & $\mathrm{x}$ & $95 / 05$ \\
\hline Uvilla/Golden berry Physalis peruviana L. & & $\mathrm{x}$ & & \\
\hline \multicolumn{5}{|l|}{ Vegeables: } \\
\hline \multirow{5}{*}{ Col/Cabbage/Brassica oleracea L. } & Head cabbage & $\mathrm{x}$ & $\mathrm{x}$ & $10 / 90$ \\
\hline & Leaf cabbage & $\mathrm{x}$ & $\mathrm{x}$ & \\
\hline & Loose leaf cabbage & $\mathrm{x}$ & $\mathrm{x}$ & \\
\hline & Hearth cabbage & $x$ & $\mathrm{x}$ & \\
\hline & Purple cabbage & $x$ & $x$ & \\
\hline \multicolumn{5}{|c|}{ Pastures (included wild species in meadows): } \\
\hline Vicia sp. & & $\mathrm{x}$ & & \\
\hline Alfalfa /Lucerne/Medicago staiva L. & & $x$ & & \\
\hline
\end{tabular}


Table A2. Cont.

\begin{tabular}{|c|c|c|c|c|}
\hline \multicolumn{5}{|c|}{ (Printable Format Sample 1) } \\
\hline \multicolumn{5}{|l|}{ Medicinal, aromatic and condiment species (planted): } \\
\hline Romero/Rosemary/Rosmarinus officinalis L. & & $x$ & & \\
\hline Yuyungilla & & $x$ & & \\
\hline Yerba Buena/Spearmint/Mentha spicata L. & & $\mathrm{x}$ & & \\
\hline Matico/Aristeguietia glutinosa (Lam.) R.M.King \& H. Rob. & & $x$ & & \\
\hline \multicolumn{5}{|c|}{ (Printable Format Sample 3) } \\
\hline \multicolumn{5}{|l|}{ 4. Agrobiodiversity (continuation) } \\
\hline \multicolumn{5}{|l|}{ Animal component } \\
\hline \multicolumn{5}{|l|}{ Livestock: } \\
\hline Species & Cultivars/Breeds & Subsistence Use & Commercial Use & Subst./Comerc. \% \\
\hline \multicolumn{5}{|l|}{ Vacas/Cattle } \\
\hline \multicolumn{5}{|l|}{ Ovejas/Sheep } \\
\hline \multicolumn{5}{|l|}{ Chivos/Goats } \\
\hline \multicolumn{5}{|l|}{ Llamas } \\
\hline \multicolumn{5}{|l|}{ Minor animals: } \\
\hline Gallinas/Chickens & & $x$ & $\mathrm{x}$ & $10 / 90$ \\
\hline Cuy/Cavy/Guinea pigs & & $\mathrm{x}$ & $\mathrm{x}$ & $10 / 90$ \\
\hline Chanchos/Pigs & & $\mathrm{x}$ & $\mathrm{x}$ & $5 / 95$ \\
\hline Conejos/Rabbits & & $x$ & & \\
\hline Palomas/Doves & & $x$ & & \\
\hline \multicolumn{5}{|c|}{ Other species/varieties component (ornamental, cultural, burden species, etc.) } \\
\hline Achera/Canna indica L. & Red & $\mathrm{x}$ & & \\
\hline \multirow{2}{*}{ Cartucho/Zantedeschia aethiopica (L.) Spreng. } & White & $\mathrm{x}$ & & \\
\hline & Green & $\mathrm{x}$ & & \\
\hline Geranio/Geranium sp. & Fuchsia & $x$ & & \\
\hline Associated biodiversity & & & & \\
\hline
\end{tabular}


Table A2. Cont.

\begin{tabular}{|c|c|}
\hline \multicolumn{2}{|c|}{ (Printable Format Sample 1) } \\
\hline \multicolumn{2}{|l|}{ Wild plants: } \\
\hline Paico / Dysphania ambrosioides (L.) Mosyakin \& Clemants & $\mathrm{x}$ \\
\hline Llantén/Grater plantain/Plantago major L. & $\mathrm{x}$ \\
\hline Verbena/Vervena sp. & $\mathrm{x}$ \\
\hline \multicolumn{2}{|l|}{ Wild animals: } \\
\hline \multicolumn{2}{|l|}{ Birds } \\
\hline Chihuako/Mirlo/Turdus sp. & $\mathrm{x}$ \\
\hline Guiragchuru/Pheucticus chrysogaster & $\mathrm{x}$ \\
\hline \multicolumn{2}{|l|}{ Reptiles } \\
\hline Lagartija negra/Black lizard & $\mathrm{x}$ \\
\hline Culebra verde/Green snake & $\mathrm{x}$ \\
\hline \multicolumn{2}{|l|}{ Amphibians } \\
\hline $\begin{array}{l}\text { Rana marsupial-Verde/Andean marsupial tree frog/Gastroteca } \\
\text { riobambae }\end{array}$ & $\mathrm{x}$ \\
\hline \multicolumn{2}{|l|}{ Mammals } \\
\hline Raposa/Common opossum/Didelphys marsupialis & $\mathrm{x}$ \\
\hline Chucuri/Long tail weasel/Mustela frenata & $\mathrm{x}$ \\
\hline \multicolumn{2}{|l|}{ Invertebrates } \\
\hline Saltamontes verde/Green grasshopper & $\mathrm{x}$ \\
\hline Catso negro/Black soil beetle-scarab & $\mathrm{x}$ \\
\hline
\end{tabular}




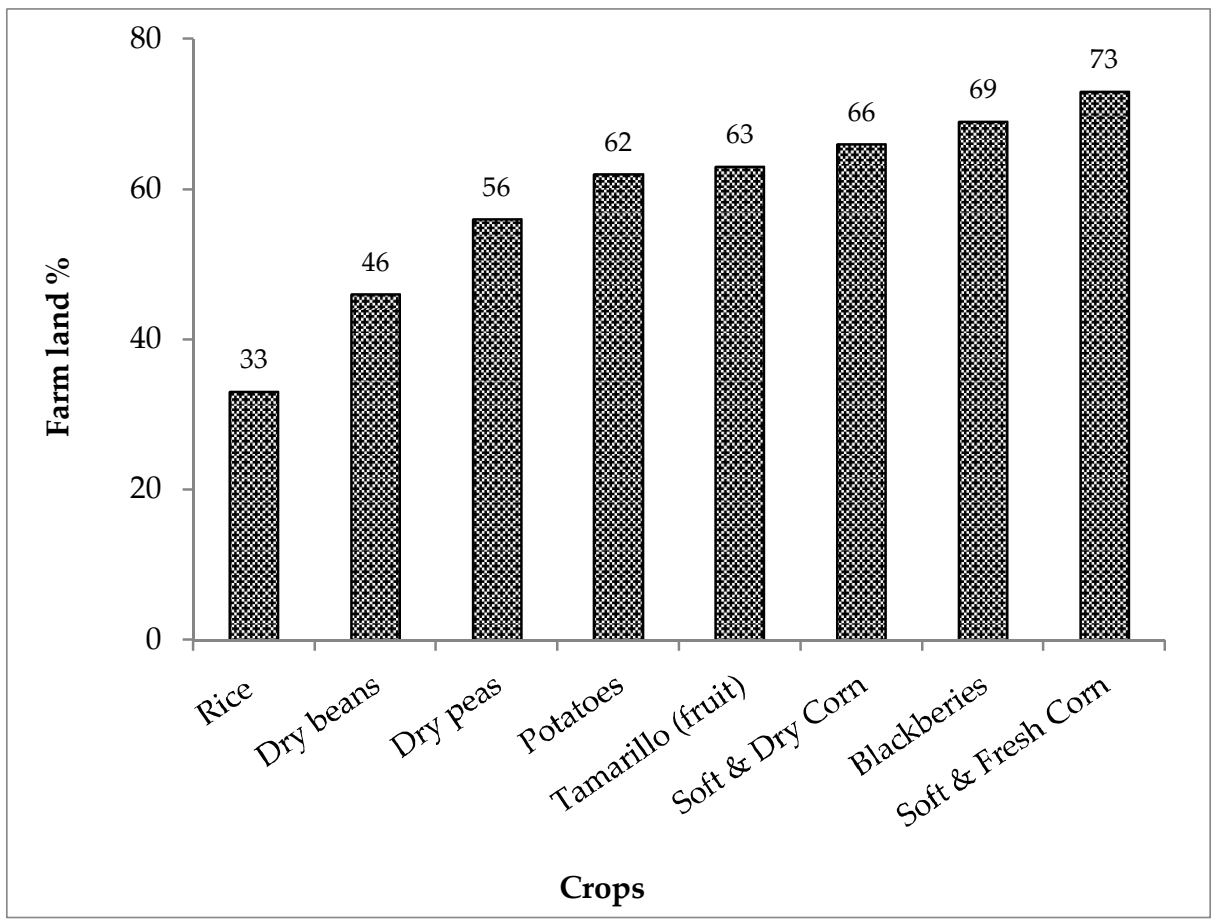

(a)

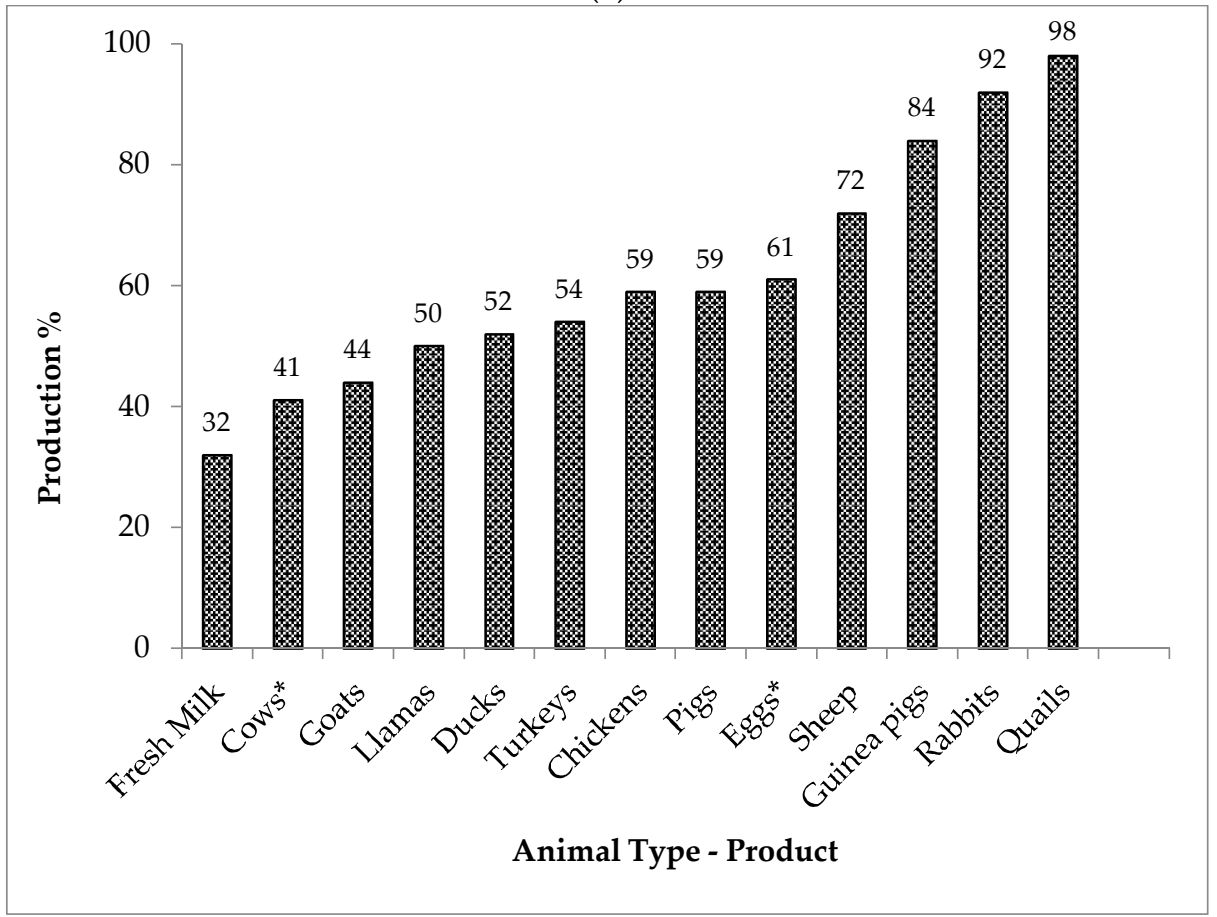

(b)

Figure A1. (a) Percentage of smallholding areas under staple crops production in Ecuador; (b) Percentage of basic food products, livestock and minor animals produced by smallholder farmers in Ecuador. * Local varieties. Source: Based on data of the national agricultural census 2000 [18].

\section{Appendix B}


Table A3. Results of main soil fertility parameters in AFS and CAS.

\begin{tabular}{|c|c|c|c|c|c|c|c|c|c|c|c|c|c|c|c|c|c|c|c|}
\hline \multirow[b]{2}{*}{ Soil Samples } & \multicolumn{19}{|c|}{ Soil Parameters $\odot$} \\
\hline & \multicolumn{2}{|c|}{$\mathrm{pH}$} & \multicolumn{2}{|c|}{$\begin{array}{c}\mathrm{CE}^{*} \\
\mathrm{dS} / \mathrm{cm}\end{array}$} & \multicolumn{2}{|c|}{$\begin{array}{c}\text { SOM }^{* *} \\
\%\end{array}$} & \multicolumn{2}{|c|}{$\begin{array}{l}\mathrm{N} \\
\%\end{array}$} & \multicolumn{2}{|c|}{$\begin{array}{c}\text { P } \\
\text { ppm }\end{array}$} & \multicolumn{2}{|c|}{$\begin{array}{c}\mathrm{K} \\
\mathrm{meq} / 100 \mathrm{~g}\end{array}$} & \multicolumn{2}{|c|}{$\begin{array}{l}\mathrm{CEC}^{* * *} \\
\mathrm{meq} / 100 \mathrm{~g}\end{array}$} & \multirow[t]{2}{*}{$\begin{array}{c}\text { Texture } \\
\text { Class }\end{array}$} & \multirow[t]{2}{*}{$\begin{array}{l}\text { BD } x \\
(\mathrm{~g} / \mathrm{cc})\end{array}$} & \multirow[t]{2}{*}{$\begin{array}{r}\mathrm{FC}^{0} \\
(\%)\end{array}$} & \multirow[t]{2}{*}{$\begin{array}{c}\mathrm{MY}^{+} \\
\text {(CFU/g) }\end{array}$} & \multirow[t]{2}{*}{$\begin{array}{l}\text { MAB } \ddagger \\
\text { (CFU/g) }\end{array}$} \\
\hline & & & & & & & & & Agr & brest & ystems & & & & & & & & \\
\hline 1 & 6.2 & $\mathrm{~L}$ & 0.3 & $\mathrm{~L}$ & 5.4 & $\mathrm{O}$ & 0.3 & $\mathrm{O}$ & 39.2 & $\mathrm{O}$ & 1.2 & $\mathrm{O}$ & 18.4 & $\mathrm{O}$ & Sandy loam & 1.2 & 35.6 & 127,000 & $1,273,000$ \\
\hline 2 & 7.2 & $\mathrm{H}$ & 0.3 & $\mathrm{~L}$ & 4.1 & $\mathrm{O}$ & 0.2 & $\mathrm{O}$ & 44.5 & $\mathrm{O}$ & 1.2 & $\mathrm{O}$ & 19.6 & $\mathrm{O}$ & Sandy loam & 1.4 & 47.9 & 54,000 & $1,640,000$ \\
\hline 3 & 6.3 & $\mathrm{~L}$ & 0.3 & $\mathrm{~L}$ & 4.8 & $\mathrm{O}$ & 0.2 & $\mathrm{O}$ & 48.8 & $\mathrm{O}$ & 0.7 & $\mathrm{O}$ & 16.6 & $\mathrm{O}$ & Sandy loam & 1.3 & 23.6 & 104,000 & 818,000 \\
\hline 4 & 7.1 & $\mathrm{H}$ & 0.3 & $\mathrm{~L}$ & 3.6 & $\mathrm{O}$ & 0.2 & $\mathrm{O}$ & 57.3 & $\mathrm{O}$ & 1.2 & $\mathrm{O}$ & 18.4 & $\mathrm{O}$ & Sandy loam & 1.4 & 34.8 & 27,000 & $1,820,000$ \\
\hline 5 & 7.7 & $\mathrm{H}$ & 0.7 & $\mathrm{O}$ & 4.2 & $\mathrm{O}$ & 0.2 & $\mathrm{O}$ & 40.6 & $\mathrm{O}$ & 2.8 & $\mathrm{H}$ & 20.9 & $\mathrm{O}$ & Sandy loam & 1.3 & 40.0 & 54,000 & $5,364,000$ \\
\hline 6 & 6.5 & $\mathrm{O}$ & 0.1 & $\mathrm{~L}$ & 3.2 & $\mathrm{O}$ & 0.2 & $\mathrm{O}$ & 31.9 & $\mathrm{O}$ & 0.7 & $\mathrm{O}$ & 19.2 & $\mathrm{O}$ & Sandy loam & 1.6 & 10.0 & 86,000 & $5,864,000$ \\
\hline 7 & 6.2 & $\mathrm{~L}$ & 0.1 & $\mathrm{~L}$ & 3.5 & $\mathrm{O}$ & 0.2 & $\mathrm{O}$ & 29.3 & $\mathrm{O}$ & 0.3 & $\mathrm{O}$ & 16.4 & $\mathrm{O}$ & Sandy loam & 1.3 & 16.1 & 180,000 & $3,864,000$ \\
\hline 8 & 6.1 & $\mathrm{~L}$ & 0.2 & $\mathrm{~L}$ & 3.4 & $\mathrm{O}$ & 0.2 & $\mathrm{O}$ & 33.6 & $\mathrm{O}$ & 0.6 & $\mathrm{O}$ & 19.7 & $\mathrm{O}$ & Sandy loam & 1.4 & 20.3 & 209,000 & $5,818,000$ \\
\hline Mean & 6.6 & $\mathrm{O}$ & 0.3 & $\mathrm{~L}$ & 4.0 & $\mathrm{O}$ & 0.2 & $\mathrm{O}$ & 40.6 & $\mathrm{O}$ & 1.1 & $\mathrm{O}$ & 18.6 & $\mathrm{O}$ & - & 1.4 & 28.5 & 105,125 & $3,307,625$ \\
\hline \multicolumn{20}{|c|}{ Conventional Agriculture Systems } \\
\hline 1 & 6.2 & $\mathrm{~L}$ & 0.2 & $\mathrm{~L}$ & 5.1 & $\mathrm{O}$ & 0.3 & $\mathrm{O}$ & 53.1 & $\mathrm{O}$ & 1.3 & $\mathrm{O}$ & 18.9 & $\mathrm{O}$ & Sandy loam & 1.4 & 28.3 & 59,000 & 182,000 \\
\hline 2 & 7.4 & $\mathrm{H}$ & 0.4 & $\mathrm{~L}$ & 3.0 & $\mathrm{~L}$ & 0.1 & $\mathrm{~L}$ & 31.3 & $\mathrm{O}$ & 0.9 & $\mathrm{O}$ & 16.7 & $\mathrm{O}$ & Sandy loam & 1.5 & 32.9 & 82,000 & $1,540,000$ \\
\hline 3 & 6.4 & $\mathrm{~L}$ & 0.4 & $\mathrm{~L}$ & 3.5 & $\mathrm{O}$ & 0.2 & $\mathrm{O}$ & 23.6 & $\mathrm{O}$ & 1.2 & $\mathrm{O}$ & 17.9 & $\mathrm{O}$ & Sandy loam & 1.6 & 31.2 & 127,000 & $3,360,000$ \\
\hline 4 & 6.7 & $\mathrm{O}$ & 0.2 & $\mathrm{~L}$ & 3.1 & $\mathrm{~L}$ & 0.2 & $\mathrm{O}$ & 17.1 & $\mathrm{O}$ & 0.7 & $\mathrm{O}$ & 15.3 & $\mathrm{O}$ & Sandy loam & 1.1 & 26.3 & 182,000 & $2,727,000$ \\
\hline 5 & 6.6 & $\mathrm{O}$ & 0.4 & $\mathrm{~L}$ & 3.1 & $\mathrm{~L}$ & 0.2 & $\mathrm{O}$ & 27.9 & $\mathrm{O}$ & 0.6 & $\mathrm{O}$ & 22.4 & $\mathrm{O}$ & Sandy loam & 1.5 & 22.8 & 109,000 & $5,636,000$ \\
\hline 6 & 7.1 & $\mathrm{H}$ & 0.1 & $\mathrm{~L}$ & 2.4 & $\mathrm{~L}$ & 0.1 & L & 0.0 & $\mathrm{~L}$ & 0.4 & $\mathrm{O}$ & 21.8 & $\mathrm{O}$ & Sandy loam & 1.6 & 38.5 & 36,000 & $4,545,000$ \\
\hline 7 & 5.9 & $\mathrm{~L}$ & 0.2 & $\mathrm{~L}$ & 3.1 & $\mathrm{O}$ & 0.2 & $\mathrm{O}$ & 14.8 & $\mathrm{~L}$ & 0.5 & $\mathrm{O}$ & 14.6 & $\mathrm{O}$ & Sandy loam & 1.5 & 40.1 & 145,000 & $7,318,200$ \\
\hline 8 & 5.8 & $\mathrm{~L}$ & 0.2 & $\mathrm{~L}$ & 4.0 & $\mathrm{O}$ & 0.2 & $\mathrm{O}$ & 14.9 & $\mathrm{~L}$ & 0.3 & $\mathrm{O}$ & 11.4 & $\mathrm{O}$ & Sandy loam & 1.0 & 30.5 & 104,000 & $5,681,800$ \\
\hline Mean & 6.5 & $\mathrm{O}$ & 0.3 & $\mathrm{~L}$ & 3.4 & $\mathrm{O}$ & 0.2 & $\mathrm{O}$ & 22.8 & $\mathrm{O}$ & 0.7 & $\mathrm{O}$ & 17.4 & $\mathrm{O}$ & - & 1.4 & 31.3 & 105,500 & $3,873,750$ \\
\hline t Sig.* & 0.590 & & 0.566 & & 0.137 & & 0.137 & & 0.015 & & 0.272 & & 0.387 & & - & 0.683 & 0.591 & 0.990 & 0.625 \\
\hline
\end{tabular}

Evaluation: $\mathrm{H}=$ High; $\mathrm{O}=$ Optimal; $\mathrm{L}=$ Low; ${ }^{*}$ Soil Electrical Conductivity; ${ }^{*}$ Soil Organic Mater; ${ }^{* * *}$ Cation Exchange Capacity; $\not$ Bulk density; ${ }^{\mathbf{0}}$ Field capacity; ${ }^{\dagger}$ Moulds and yeast; Mesophilic aerobic bacteria; Analyis methods: $\mathrm{pH}$ : 1:1.25 $\mathrm{H}_{2} \mathrm{O}$; SOM: 0.1-0.5 $\mathrm{K}_{2} \mathrm{Cr}_{2} \mathrm{O}_{7}$ 0.8 N; P \& K: Modified Olsen ; CEC: Ammonium Acetate $1 \mathrm{~N}$ pH 7.0; CE: Saturated Paste; BD and FC: Physical methods; Moulds and yeast/Mesophilic aerobic bacteria: AOAC 990.12 (Petrifilm); $\odot$ Evaluated and analysed by the water and soil laboratory of the Salesian Polytechnic University, Cayambe-Ecuador. 
Table A4. Main microclimate parameters differences between AFS and CAS.

\begin{tabular}{|c|c|c|c|c|c|c|c|c|c|}
\hline Inside Farm Records & $\begin{array}{l}\text { Temp } \\
\left({ }^{\circ} \mathrm{C}\right)\end{array}$ & $\begin{array}{l}\text { Temp High } \\
\left({ }^{\circ} \mathrm{C}\right)\end{array}$ & $\begin{array}{c}\text { Temp Low } \\
\left({ }^{\circ} \mathrm{C}\right)\end{array}$ & $\begin{array}{l}\text { Humidity } \\
(\%)\end{array}$ & $\begin{array}{c}\text { Dew Point } \\
\left({ }^{\circ} \mathrm{C}\right)\end{array}$ & $\begin{array}{l}\text { Wind Speed } \\
(\mathrm{m} / \mathrm{s})\end{array}$ & $\begin{array}{l}\text { Wind High Speed } \\
(\mathrm{m} / \mathrm{s})\end{array}$ & $\begin{array}{l}\text { Wind Chill } \\
\left({ }^{\circ} \mathrm{C}\right)\end{array}$ & $\begin{array}{l}\text { Heat Index } \\
\left({ }^{\circ} \mathrm{C}\right)\end{array}$ \\
\hline \multicolumn{10}{|c|}{ Agroforestry systems } \\
\hline 1 & 16.1 & 16.4 & 15.7 & 78.2 & 11.9 & 2.3 & 5.2 & 15.6 & 16.0 \\
\hline 2 & 14.8 & 15.0 & 14.6 & 85.2 & 11.9 & 1.3 & 3.0 & 14.7 & 14.9 \\
\hline 3 & 15.4 & 15.7 & 15.2 & 94.3 & 14.4 & 0.3 & 1.5 & 15.4 & 15.8 \\
\hline 4 & 17.0 & 17.5 & 16.6 & 82.6 & 13.7 & 1.0 & 3.2 & 17.0 & 17.3 \\
\hline 5 & 18.2 & 18.6 & 17.8 & 80.2 & 14.4 & 0.9 & 3.8 & 18.2 & 18.5 \\
\hline 6 & 16.3 & 16.6 & 16.1 & 95.4 & 15.5 & 1.3 & 3.1 & 16.3 & 16.7 \\
\hline 7 & 17.7 & 18.0 & 17.3 & 88.9 & 15.6 & 1.0 & 2.7 & 17.7 & 18.1 \\
\hline 8 & 16.7 & 17.1 & 16.4 & 90.6 & 15.0 & 0.8 & 2.7 & 16.7 & 17.1 \\
\hline Mean & 16.5 & 16.9 & 16.2 & 86.9 & 14.1 & 1.1 & 3.1 & 16.5 & 16.8 \\
\hline \multicolumn{10}{|c|}{ Conventional agricultural systems } \\
\hline 1 & 15.9 & 16.2 & 15.6 & 91.8 & 14.5 & 1.1 & 3.0 & 15.9 & 16.2 \\
\hline 2 & 16.5 & 16.7 & 16.2 & 94.2 & 15.4 & 0.3 & 1.6 & 16.5 & 16.9 \\
\hline 3 & 16.4 & 16.8 & 16.0 & 80.2 & 12.7 & 2.1 & 4.7 & 16.1 & 16.5 \\
\hline 4 & 16.2 & 16.6 & 15.8 & 83.0 & 13.0 & 1.0 & 3.1 & 16.2 & 16.4 \\
\hline 5 & 17.2 & 17.6 & 16.8 & 79.6 & 13.4 & 2.6 & 6.4 & 16.9 & 17.3 \\
\hline 6 & 15.2 & 15.5 & 14.9 & 87.6 & 12.9 & 2.0 & 3.8 & 14.9 & 15.3 \\
\hline 7 & 15.2 & 15.6 & 14.9 & 92.6 & 13.9 & 1.0 & 2.7 & 15.2 & 15.6 \\
\hline 8 & 16.8 & 17.1 & 16.5 & 86.8 & 14.5 & 2.2 & 6.1 & 16.6 & 17.1 \\
\hline Mean & 16.2 & 16.5 & 15.8 & 87.0 & 13.8 & 1.5 & 3.9 & 16.0 & 16.4 \\
\hline tSig. * & 0.437 & 0.483 & 0.407 & 0.989 & 0.670 & 0.238 & 0.281 & 0.394 & 0.430 \\
\hline
\end{tabular}




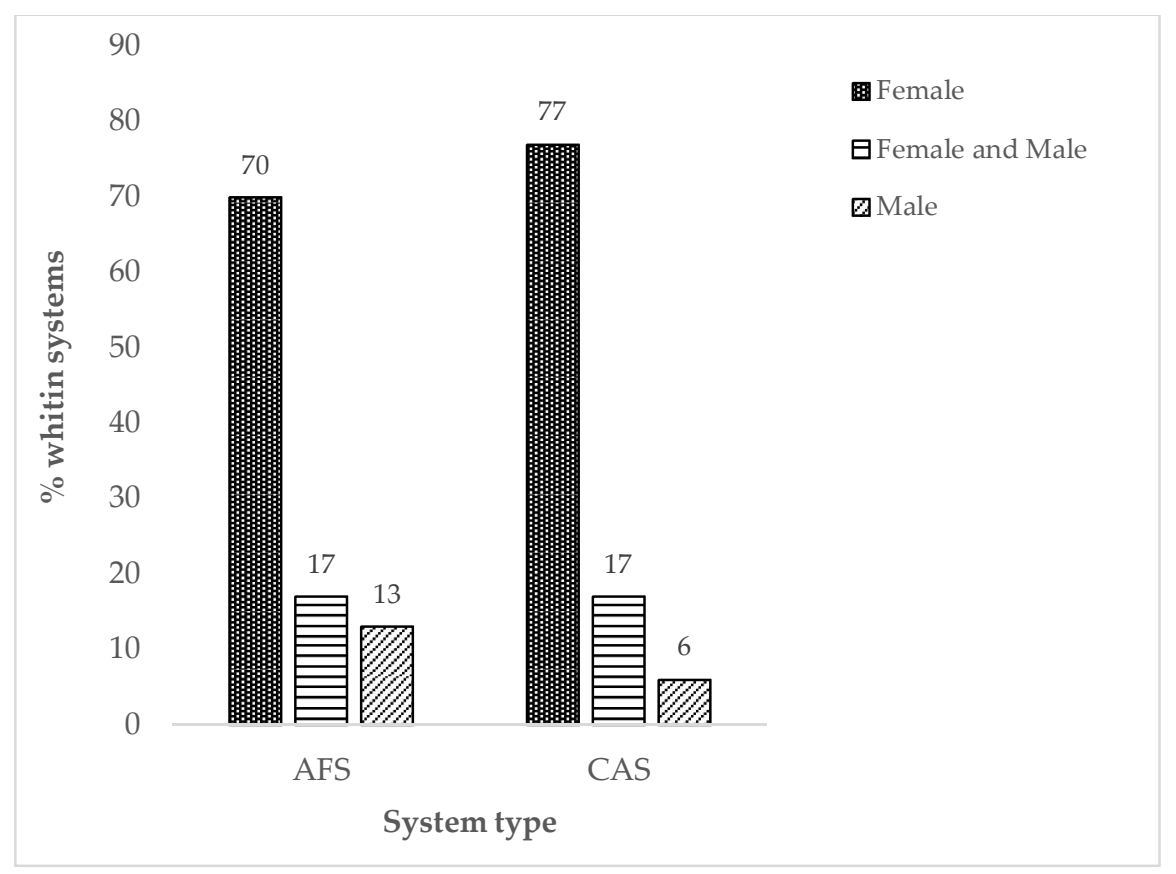

Figure A2. Gender of the main household head system type.

\section{References}

1. Lowder, S.K.; Skoet, J.; Raney, T. The number, size, and distribution of farms, smallholder farms, and family farms worldwide. World Dev. 2016, 87, 16-29. [CrossRef]

2. Food and Agriculture Organization of the United Nations. Smallholders and Family Farmers Factsheet. Available online: http:/ / www.fao.org/fileadmin/templates/nr/sustainability_pathways/docs/Factsheet_ SMALLHOLDERS.pdf (accessed on 3 November 2016).

3. Rapsomanikis, G. The Economic Lives of Smallholder Farmers: An Analysis Based on Household Data from Nine Countries; I5251E/1/12.15; Food and Agriculture Organization of the United Nations (FAO): Rome, Italy, 2015.

4. Berdegué, J.A.; Fuentealba, R. Latin america: The state of smallholders in agriculture. In New Directions for Smallholder Agriculture; International Fund for Agricultural Development: Rome, Italy, 2011.

5. Vadjunec, J.; Radel, C.; Turner, B., II. Introduction: The continued importance of smallholders today. Land 2016, 5, 34. [CrossRef]

6. Soto, B.; Rodriguez, M.; Falconí, C. (Eds.) Políticas Para la Agricultura Familiar en America Latina y el Caribe, 1st ed.; Organización de las Naciones Unidas para la Alimentación y Agricultura-FAO: Santiago, Chile, 2007.

7. Graeub, B.E.; Chappell, M.J.; Wittman, H.; Ledermann, S.; Kerr, R.B.; Gemmill-Herren, B. The state of family farms in the world. World Dev. 2016, 87, 1-15. [CrossRef]

8. Costantino, A. Land grabbing in latin america: Another natural resource curse? Agrar. South J. Political Econ. 2014, 3, 17-43. [CrossRef]

9. Borras, S., Jr.; Franco, J.; Kay, C.; Spoor, M. El acaparamiento de tierras en américa latina y el caribe visto desde una perspectiva internacional más amplia. In Reflexiones Sobre la Concentración y Extranjerización de la Tierra en América Latina y el Caribe; Baquero, F., Gómez, S., Eds.; FAO: Santiago, Chile, 2014; pp. 15-68.

10. Baquero, F.; Gómez, S. (Eds.) Reflexiones Sobre la Concentración y Extranjerización de la Tierra en América Latina y el Caribe; FAO: Santiago, Chile, 2014.

11. De Ferranti, D.M. Inequality in Latin America: Breaking with History?; The World Bank: Washington, DC, USA, 2004.

12. Michael, L.; Salcedo, S.; Jara, B.; Boero, V.; Muñoz, M. La agricultura familiar en cifras. In Agricultura Familiar en America Latina y el Caribe: Recomendaciones de Política; Salcedo, S., Guzmán, L., Eds.; FAO: Santiago, Chile, 2014; pp. 35-56. 
13. Altieri, M.A.; Funes-Monzote, F.R.; Petersen, P. Agroecologically efficient agricultural systems for smallholder farmers: Contributions to food sovereignty. Agron. Sustain. Dev. 2012, 32, 1-13. [CrossRef]

14. Isch, L.E.; Zapatta, A. Tierra y Agua: Interrelaciones de un Acceso Inequitativo; Sistema de Investigación Sobre la Problemática Agraria en el Ecuador: Quito, Ecuador, 2010.

15. Carrión, D.; Herrera, S. Ecuador Rural del Siglo xxi: Soberanía Alimentaria, Inversión Pública y Política Agraria; Instituto de Estudios Ecuatorianos: Quito, Ecuador, 2012.

16. Brassel, F.; Herrera, S.; Laforge, M. Reforma Agraria en el Ecuador: Viejos Temas, Nuevos Argumentos; Sistema de Investigación Sobre la Problemática Agraria en el Ecuador: Quito, Ecuador, 2008.

17. Larrea, C. Tenencia de la tierra, cambios agrarios y etnicidad indígena en el ecuador: 1954-2000. In Desarrollo Rural y Neoliberalismo: Ecuador desde una Perspectiva Comparada; North, L., Cameron, J., Eds.; Universidad Andina Simón Bolívar-Corporación Editora Nacional: Quito, Ecuador, 2008.

18. INEC. Resultados Nacionales con Resúmenes Provinciales, Censo Nacional Agropecuario 2000. Available online: http:/ / www.ecuadorencifras.gob.ec/censo-nacional-agropecuario/ (accessed on 11 October 2016).

19. Barragán, C.; Cahuasquí, L.; Landívar, N.; Ruiz, M. El Derecho a la Alimentación en el Ecuador: Balace del Estado Alimentario de la Población Ecuatoriana desde una Perpectiva de Derechos Humanos; Foodfirst Information and Action Network-FIAN Ecuador: Quito, Ecuador, 2010.

20. Gaybor, A. Acumulación Capitalista en el Campo y Despojo de Agua; Foro de los Recursos Hídricos: Quito, Ecuador, 2010.

21. Tamayo, C.; Francisco, H. Dificultades y Desafíos para el Riego Campesino; Todos por el agua, el agua para Todos. Quinto Encuenro Nacional. Documentos de Discusión, Portoviejo and Montecristi-Ecuador, 2008; Isch, E., Ed.; Foro de los Recuros Hídricos-Consorcio CAMAREN: Portoviejo, Ecuador, 2008; pp. 159-173.

22. Salcedo, S.; Sanchez, A.; Coloma, M. Agricultura familiar y la seguridad alimentaria: El exitoso caso de forsandino. In Agricultura Familiar en America Latina y el Caribe: Recomendaciones de Política; Salcedo, S., Guzmán, L., Eds.; FAO: Santiago, Chile, 2014; pp. 58-78.

23. Oyarzun, P.J.; Borja, R.M.; Sherwood, S.; Parra, V. Making sense of agrobiodiversity, diet, and intensification of smallholder family farming in the highland andes of ecuador. Ecol. Food Nutr. 2013, 52, 515-541. [CrossRef] [PubMed]

24. Guerrero, A.; Salvador, S. Panorama Agroeconómico del Ecaudor, una Visión del 2015. Available online: http: / / sinagap.agricultura.gob.ec/pdf/estudios_agroeconomicos/panorama_agroeconomico_ecuador2015.pdf (accessed on 3 February 2017).

25. Altieri, M.A.; Toledo, V.M. The agroecological revolution in latin america: Rescuing nature, ensuring food sovereignty and empowering peasants. J. Peasant Stud. 2011, 38, 587-612. [CrossRef]

26. Van Noordwijk, M.; Bayala, J.; Hairiah, K.; Lusiana, B.; Muthuri, C.; Khasanah, N.M.; Mulia, R. Agroforestry solutions for buffering climate variability and adapting to change. In Climate Change Impact and Adaptation in Agricultural Systems; Fuhrer, J., Gregory, P.J., Eds.; CAB-International: Wallingford, UK, 2014; pp. $216-232$.

27. Maldonado, P. Mapa del Territorio de la Confederación del Pueblo Kayambi; Confederación del Pueblo Kayambi: Cayambe, Ecuador, 2016.

28. Pilataxi, C. Plan Estratégico de Desarrollo del Pueblo Kayambi; Confederación del Pueblo Kayambi: Cayambe, Ecuador, 2001.

29. INEC. Población, Superficie $\left(\mathrm{km}^{2}\right)$, Densidad Poblacional a Nivel Parroquial. Available online: http://www. ecuadorencifras.gob.ec/informacion-censal-cantonal/ (accessed on 5 October 2016).

30. Becker, M. Pueblo Kayambi. Available online: http://www.kayambi.org/index.html (accessed on 10 January 2016).

31. Knapp, G. Andean Ecology: Adaptive Dynamics in Ecuador; Westview: Boulder, CO, USA; Oxford, UK, 1991.

32. Cañadas, L. El Mapa Bioclimático y Ecológico del Ecuador; Banco Central del Ecuador: Quito, Ecuador, 1983.

33. Medina, G.; Mena, P. Los páramos en el ecuador. In Los Páramos del Ecuador. Particularidades, Problemas y Perspectivas; Medina, G., Mena, P., Hofstede, R., Eds.; Abya Yala: Quito, Ecuador, 2001; pp. 1-23.

34. Moreno, L. Actualización del Plan de Desarrollo y Ordenemiento Territorial del Gobierno Autónomo Descentralizado Intercultural y Plurinacional Municipal de Cayambe 2015-2025; GADIP Cayambe: Cayambe, Ecuador, 2015.

35. INAMHI. Mapa de Precipitación Media Multianual (1965-1999). Available online: http://www. serviciometeorologico.gob.ec/wp-content/MapasBiblioteca/5\%20PrecipitacionA0.pdf (accessed on 3 January 2017). 
36. López, M. Generación de geo Información para la Gestión del Territorio a Nivel Nacional, Escala 1: 25,000, Sistemas Productivos Cantón Cayambe; Instituto Espacial Ecuatoriano y Gobierno Autónomo Descentralizado Provincia de Pichincha: Quito, Ecuador, 2013.

37. INEC. Población por Área, Según Provincia, Cantón y Parroquia de Empadronamiento y Grupos Étnicos. Available online: http:/ / www.ecuadorencifras.gob.ec/informacion-censal-cantonal/ (accessed on 13 January 2017).

38. SIISE. Pobreza por Necesidades Básicas Insatisfechas (nbi). Available online: http://www.siise.gob.ec/ siiseweb/ siiseweb.html? sistema=1\# (accessed on 13 February 2017).

39. Hofstede, R. El impacto de las actividades humanas sobre el páramo. In Los Páramos del Ecuador. Particularidades, Problemas y Perspectivas; Mena, P., Medina, G., Hofstede, R., Eds.; Abya Yala: Quito, Ecuador, 2001; pp. 161-185.

40. CODEMIA. Sistematización y Análisis de los Resultados de la Caracterización Agropecuaria y Mapas Temáticos del Sistema de Riego Cayambe - Pedro Moncayo; Consorcio de Desarrollo de Manejo Integral de Agua y Ambiente: Cayambe, Ecuador, 2015.

41. Zomer, R.J.; Trabucco, A.; Coe, R.; Place, F.; van Noordwijk, N.; Xu, J.C. Trees on Farms: An Update and Reanalysis of Agroforestry's Global Extent and Socio-ecological Characteristics. Working Paper 179. Available online: http:/ / www.worldagroforestry.org/downloads/Publications/PDFS/WP14064.pdf (accessed on 10 May 2015).

42. Hofstede, R.; Lips, J.; Jongsma, W. Geografía, Ecología y Forestación de la Sierra alta del Ecuador; Abya Yala: Quito, Ecuador, 1998.

43. Spargo, J.; Allen, T.; Kariuki, S. Interpreting Your Soil Test Results. Available online: http://ag.umass.edu/ soil-plant-tissue-testing-lab/fact-sheets / interpreting-your-soil-test-results (accessed on 12 June 2016).

44. Espinoza, L.; Slaton, N.; Mozaffari, M. Understanding the Numbers on Your Soil Test Report. Available online: https:/ / www.uark.edu/depts/soiltest/NewSoilTest/pdf_files/FSA-2118.pdf (accessed on 13 June 2016).

45. Hull, W.X. Manual de Conservación de Suelos; Mexico, D.F., Ed.; Servicio de Lenguas Extranjeras, Secretaría de Estado de los Estados Unidos de América: Whashington, DC, USA, 1992; p. 331.

46. What Is Sandy Loam. Available online: http://www.southernmulch.com/article-what-is-sandy-loam.php (accessed on 15 June 2017).

47. Kavdir, Y.; Zhang, W.; Basso, B.; Smucker, A.J.M. Development of a New Long-term Drought Resilient Soil Water Retention Technology. Available online: http:/ / www.jswconline.org/content/69/5/154A.full.pdf+ html?sid=cf76b9ac-4e83-4f03-9da9-841cd72324b0 (accessed on 21 June 2017).

48. USDA, Natural Resources Conservation Service. Rangeland Sheet 4, Rangeland Soil Quality-compaction. Available online: https://www.nrcs.usda.gov/Internet/FSE_DOCUMENTS/nrcs142p2_051912.pdf (accessed on 20 June 2017).

49. USDA, Natural Resources Conservation Service. Soil Bulk Density/Moisture/Aireation, Soil Quality Kit-guides for Educators. Available online: https:/ /www.nrcs.usda.gov/Internet/FSE_DOCUMENTS / nrcs142p2_053260.pdf (accessed on 22 June 2017).

50. Suquilanda, M. Manejo Agroecológico de Suelos, 1st ed.; Ministerio de Agricultura, Ganadería, Acuacultura y Pesca: Quito, Ecuador, 2017; p. 32.

51. Cornell University. Northeast Region Certified Crop Adviser (NRCCA) Study Resources; Competency Area 2: Soil Hydrology Aem; po 12.1-3 Field Capacity, Permanent Wilting Point \& Available Water Capacity. Available online: https:/ /nrcca.cals.cornell.edu/soil/CA2/CA0212.1-3.php (accessed on 23 June 2017).

52. Zimmerer, K.S. Overlapping patchworks of mountain agriculture in peru and bolivia: Toward a regional-global landscape model. Hum. Ecol. 1999, 27, 135-165. [CrossRef]

53. Beniston, M. Climatic change in mountain regions: A review of possible impacts. Clim. Chang. 2003, 59, 5-31. [CrossRef]

54. Price, M.F. Climate change in mountain regions: A marginal issue? Environmentalist 1995, 15, $272-280$. [CrossRef]

55. De Boef, W.; Haga, M.; Sibanda, L.; Swaminathan, M.; Winters, P. (Eds.) Mainstreaming Agrobiodiversity in Sustainable Food Systems: Scientific Foundations for an Agrobiodiversity Index-Summary; Biodiversity International: Rome, Italy, 2016; p. 30. 
56. Biodiversity and Agriculture: Safeguarding Biodiversity and Securing Food for the World. Available online: https:/ / www.cbd.int/doc/bioday/2008/ibd-2008-booklet-en.pdf (accessed on 29 May 2017).

57. Thrupp, L.A. The importance of biodiversity in agroecosystems. J. Crop Improv. 2004, 12, 315-337. [CrossRef]

58. Leakey, R. Socially modified organisms in multifunctional agriculture-Addressing the needs of smallholder farmers in africa. Arch. Crop Sci. 2017, 1, 20-29.

59. Pascual, U.; Narloch, U.; Nordhagen, S.; Drucker, A. The economics of agrobiodiversity conservation for food security under climate change. Economia Agraria y Recursos Naturales 2011, 11, 191-220. [CrossRef]

60. Zimmerer, K.; Vanek, S. Toward the integrated framework analysis of linkages among agrobiodiversity, livelihood diversification, ecological systems, and sustainability amid global change. Land 2016, 5, 10. [CrossRef]

61. Sconnes, I. Sustainable Rural Livelihoods: A Framework for Analysis. Available online: https:/ /opendocs. ids.ac.uk/opendocs / bitstream/handle/123456789/3390/Wp72.pdf?sequence=1 (accessed on 6 December 2017).

62. Chambers, R.; Conway, G. Sustainable Rural Livelihoods: Practical Concepts for the 21st Century. Available online: https:/ / opendocs.ids.ac.uk/opendocs/bitstream/handle/123456789/775/Dp296.pdf?sequence=1 (accessed on 28 November 2017).

63. Chiriboga, M. La pobreza rural y la producción agropecuaria. In Ecuador: El mito del Desarrollo; Editorial El Conejo: Quito, Ecuador, 1982.

64. Wong, S.; Ludeña, C. Caracterización de la Agricultura Familiar en Ecuador. Preliminary Report 1. Proyecto gcp/rla/152/iab; FAO: Quito, Ecuador, 2006.

65. Hussein, K.; Nelson, J. Sustainable Livelihoods and Livelihood Diversification. Available online: http: / / www.ids.ac.uk/ files/Wp69.pdf (accessed on 19 December 2017).

66. Ellis, F. The determinants of rural livelihood diversification in developing countries. J. Agric. Econ. 2000, 51, 289-302. [CrossRef]

67. Ampudia, L. (Ed.) Impacto de la Floricultura en los Campesinos de Cayambe; Instituto de Ecología y Desarrollo de las Comunidades Andinas (IEDECA): Cayambe, Ecuador, 1999; p. 108.

68. Ávalos, D. Dinámicas de Agricultura Familiar en Torno a la Existencia de la Producción Florícola en la Parroquia Tabacundo, Ecuador; Facultad Latinomaericana de Ciencias Sociales, FLACSO Ecuador: Quito, Ecuador, 2017.

69. Newman, C.; Larreamendy, P.; Maldonado, A. Mujeres y Floricultura, Cambios y Consecuencias en el Hogar; Abya-Yala, World Bank and CONAMU: Quito, Ecuador, 2002; p. 86.

70. Vega, H.; Philhower, E. 2009 Ecuador Fresh Flower Industry Situation. Available online: https: / / gain.fas.usda.gov / Recent\%20GAIN\%20Publications /2009\%20Ecuador\%20Fresh\%20Flower\% 20Industry\%20Situation_Quito_Ecuador_6-9-2009.pdf (accessed on 12 January 2018).

71. Conefrey, M. Roses with Altitude: Why Ecuador's Flower Industry Stands Out. Available online: https: / / www.ft.com/content/eb5114d6-d846-11e4-ba53-00144feab7de (accessed on 12 January 2018).

72. Martínez, L. La Agricultura Familiar en el Ecuador. Available online: http:/ / portalsiget.net/ArchivosSIGET/ recursos / Archivos/1682015_AgriculturaFamiliarE.pdf (accessed on 22 December 2017).

73. Feder, G. Land ownership security and farm productivity: Evidence from thailand. J. Dev. Stud. 1987, 24, 16-30. [CrossRef]

74. FAO. Land Tenure and Rural Development. Available online: ftp://ftp.fao.org/docrep/fao/005/y4307E/ y4307E00.pdf (accessed on 26 August 2017).

75. Lasco, R.D.; Delfino, R.J.P.; Espaldon, M.L.O. Agroforestry systems: Helping smallholders adapt to climate risks while mitigating climate change. Wiley Interdiscip. Rev. Clim. Chang. 2014, 5, 825-833. [CrossRef]

76. Selvarajh-Jaffery, R.; Obanyi, G.; Wagner, B.; Sulzberger, E. (Eds.) Tackling Global Challenges through Agroforestry. Annual Report 2006; World Agroforestry Centre (ICRAF): Nairobi, Kenya, 2007; p. 60.

77. Watson, R.T.; Noble, I.R.; Bolin, B.; Ravindranath, N.H.; Verardo, D.J.; Dokken, D.J. (Eds.) Land Use, Land-Use Change and Forestry. Special Reports; IPCC: Cambridge, UK, 2000; p. 375.

(C) 2018 by the authors. Licensee MDPI, Basel, Switzerland. This article is an open access article distributed under the terms and conditions of the Creative Commons Attribution (CC BY) license (http:// creativecommons.org/licenses/by/4.0/). 